Periprocedural Bridging in Patients with Venous Thromboembolism:

A Systematic Review

Christine Baumgartner MD, MAS, Ivan de Kouchkovsky MD , Evans Whitaker MD, MLIS, Margaret C. Fang MD, MPH

PII: S0002-9343(19)30064-6

DOI: https://doi.org/10.1016/j.amjmed.2019.01.004

Reference: AJM 14977

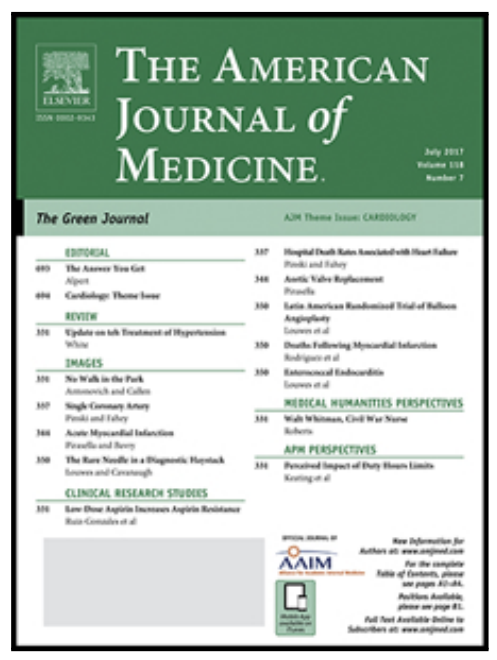

To appear in:

The American Journal of Medicine

Please cite this article as: Christine Baumgartner MD, MAS, Ivan de Kouchkovsky MD, Evans Whitaker MD, MLIS , Margaret C. Fang MD, MPH, Periprocedural Bridging in Patients with Venous Thromboembolism: A Systematic Review, The American Journal of Medicine (2019), doi: https://doi.org/10.1016/j.amjmed.2019.01.004

This is a PDF file of an unedited manuscript that has been accepted for publication. As a service to our customers we are providing this early version of the manuscript. The manuscript will undergo copyediting, typesetting, and review of the resulting proof before it is published in its final form. Please note that during the production process errors may be discovered which could affect the content, and all legal disclaimers that apply to the journal pertain. 


\section{Periprocedural Bridging in Patients with Venous Thromboembolism: A}

\section{Systematic Review}

First Author: Baumgartner

Short Title: Periprocedural Bridging in Venous Thromboembolism

Type of Manuscript: Review

\section{Authors}

Christine Baumgartner, MD, MAS ${ }^{1,2}$; Ivan de Kouchkovsky, MD ${ }^{1}$; Evans Whitaker, MD, MLIS ${ }^{3}$; Margaret C. Fang, MD, $\mathrm{MPH}^{1}$

\section{Affiliations}

${ }^{1}$ Division of Hospital Medicine, University of California, San Francisco, San Francisco, CA

${ }^{2}$ Department of General Internal Medicine, Inselspital, Bern University Hospital, University of Bern, Bern, Switzerland

${ }^{3}$ UCSF Medical Library, University of California, San Francisco, San Francisco, CA

\section{Corresponding Author}

MargaretC. Fang, MD, MPH, University of California, San Francisco, 533 Parnassus Ave., Box 0131, room U135, San Francisco, CA 94143. Phone: (415) 502-7100; Fax: (415) 514-2094; e-mail: Margaret.Fang@ucsf.edu.

Keywords: bridging, anticoagulants, periprocedural, venous thromboembolism, bleeding 
Registration: PROSPERO, registration number CRD42017074710

Text word count (including abstract): 2996, Abstract word count: 248, Tables: 4, Figures: 1, Number of References: 51 
Periprocedural Bridging in Patients with Venous Thromboembolism: A Systematic

\section{Review}

\section{Clinical Significance}

Word count: 60

- Periprocedural bridging is widely used in patients with previous venous thromboembolism who require interruption of vitamin $\mathrm{K}$ antagonists due to an invasive procedure

- This systematic review found that periprocedural bridging in patients with previous venous thromboembolism increases the risk of bleeding without reducing the risk of periprocedural venous thromboembolism

- Most patients with venous thromboembolism do not benefit from periprocedural bridging 


\section{Abstract \\ Background}

Vitamin K antagonists (VKA) are the most widely used anticoagulants, and bridging is commonly administered during periprocedural VKA interruption. Given the unclear benefits and risks of periprocedural bridging in patients with previous venous thromboembolism, we aimed to assess recurrent venous thromboembolism and bleeding outcomes with and without bridging in this population.

\section{Methods}

We performed a systematic review searching the PubMed and EMBASE databases from inception to December 7, 2017 for randomized and non-randomized studies that included adults with previous venous thromboembolism requiring VKA interruption to undergo an elective procedure, and that reported venous thromboembolism or bleeding outcomes. Quality of evidence was graded by consensus.

\section{Results}

We included 28 cohort studies (20 being single-arm cohorts) with overall 6915 procedures for analysis. In 27 studies reporting perioperative venous thromboembolism outcomes, the pooled incidence of recurrent venous thromboembolism with bridging was $0.7 \%$ (95\% confidence interval [Cl] $0.4-1.2 \%)$ and $0.5 \%(95 \% \mathrm{Cl} 0.3-0.8 \%)$ without bridging. Eighteen studies reported major and/or non-major bleeding outcomes. The pooled incidence of any bleeding was 3.9\% (95\% $\mathrm{Cl} 2.0-7.4 \%)$ with bridging and $0.4 \%(95 \% \mathrm{Cl} 0.1-1.7 \%)$ without bridging. In bridged patients at high thromboembolic risk, the pooled incidence for venous thromboembolism was $0.8 \%$ (95\% $\mathrm{Cl} 0.3-2.5)$ and $7.5 \%$ (95\% $\mathrm{Cl} 3.1-17.4 \%)$ for any bleeding. Quality of available evidence was very low, primarily due to a high risk of bias of included studies.

\section{Conclusions}

Periprocedural bridging increases the risk of bleeding compared to VKA interruption without bridging, without a significant difference in periprocedural venous thromboembolism rates. 


\section{Introduction}

Among >6 million individuals in the US who are on chronic anticoagulation, about 250,000 patients each year need to temporarily interrupt their anticoagulants before an invasive procedure to diminish the risk of excess periprocedural bleeding. ${ }^{1}$ Despite the rapid adoption of direct oral anticoagulants (DOACs) in recent years, vitamin $\mathrm{K}$ antagonists (VKAs) remain the most frequently prescribed anticoagulants in the US and worldwide. ${ }^{2,3}$ VKAs must be interrupted several days prior to a procedure to allow for regeneration of vitamin $\mathrm{K}$ dependent coagulation factors and subsequent normalization of coagulation. ${ }^{1}$ Because of the concern of an increased risk of thromboembolism during VKA interruption, periprocedural bridging with short-acting parenteral anticoagulants has been recommended for individuals at high thromboembolic risk.

A previous systematic review investigated periprocedural bridging in patients on VKAs for any indication and found an increased bleeding risk in bridged compared to non-bridged patients without a difference in thromboembolic risk. ${ }^{5}$ Similarly, a randomized trial of atrial fibrillation patients showed no difference in thromboembolic outcomes, but a significantly higher incidence of major bleeding with bridging compared with placebo. ${ }^{6}$ However, less is known about the risks and benefits of bridging in patients anticoagulated for venous thromboembolism. A recent retrospective study found an increased bleeding risk with bridging, but no substantial risk of recurrent venous thromboembolism without bridging, irrespective of estimated thromboembolic risk, ${ }^{7}$ suggesting that current guidelines fail to identify patients with high enough thromboembolic risk to justify bridging.

To better define risks and benefits of bridging in patients with previous venous thromboembolism requiring VKA interruption to undergo an elective invasive procedure, we performed a systematic review comparing recurrent venous thromboembolism and bleeding outcomes with and without periprocedural bridging. 


\section{Methods}

We conducted this systematic review according to the protocol registered on PROSPERO (registration number CRD42017074710), and reporting conformed to the Preferred Reporting Items for Systematic Reviews and Meta-Analyses (PRISMA) statement. ${ }^{8}$

\section{Data Sources and Searches}

We performed a systematic literature review of articles in PubMed and EMBASE, from inception to December 7, 2017, without language restrictions (Supplemental Methods 1). We also considered conference proceedings, and screened bibliographies of retrieved articles, the most recent American College of Chest Physicians (ACCP) guidelines, and two previous systematic reviews on periprocedural anticoagulation. ${ }^{1,5,9}$ We searched for unpublished literature in the ClinicalTrials.gov and International Clinical Trials Registry Platform (ICTRP) databases.

\section{Study Selection}

We included original articles of randomized trials and observational studies that enrolled adults on long-term VKA therapy for secondary prophylaxis of venous thromboembolism who required anticoagulation interruption to undergo elective invasive procedures. Studies were eligible for inclusion if they assessed venous thromboembolism and/or bleeding outcomes in patients with or without heparin bridging; single-arm studies were also considered. Studies that did not specifically report outcomes for the population of interest or studies including <10 venous thromboembolism patients were excluded. Two physicians (C.B. and I.d.K.) independently screened titles and abstracts for eligibility, and in a second step, full-text articles of references selected in the first screening phase were screened (Figure 1). Disagreement was resolved by discussion. NonEnglish articles were translated by native speakers.

\section{Data Extraction and Quality Assessment}

We extracted pre-specified data on study design, population characteristics, thromboembolic risk, invasive procedures, anticoagulation management strategies, and study 
sponsors. In the absence of a universally accepted definition, ${ }^{1}$ bridging was classified as receipt of prophylactic, intermediate, or therapeutic doses of any heparin in the perioperative period. Data on patients who continued VKA perioperatively were not included, because our research question related to patients who required interruption of anticoagulation. The primary outcome was recurrent venous thromboembolism including deep vein thrombosis and pulmonary embolism (as ascertained by the individual studies) within 30 days postoperatively. ${ }^{10}$ Other follow-up periods were used if 30-day outcomes were not reported, as done previously. ${ }^{11}$ Secondary outcomes included major bleeding (according to the definition used in the individual studies), and any major and nonmajor bleeding. Outcome data were extracted by two independent investigators, If outcomes were not specifically reported for the population of interest, we contacted study authors to request the information; 3 authors provided additional data. ${ }^{12-14}$

Two independent reviewers (C.B. and I.d.K) assessed individual study quality using criteria adapted from the ACCP Antithrombotic Therapy and Prevention of Thrombosis, $9^{\text {th }}$ edition; ${ }^{5,15}$ this approach was chosen because it is applicable to single-arm studies. Items to assess quality of observational studies included consecutive enrollment, the existence of a study protocol prior to enrolment, the similarity of the setting and time frame of intervention and control groups, blinded outcome assessment, and loss to follow-up., ${ }^{5,15}$ Nonrandomized studies were considered to be at high risk of bias and were downgraded to moderate risk if the study accounted for and reported all of the quality elements. On the other hand, they were upgraded to very high risk if they used a single-arm cohort design, ${ }^{16}$ or if there were severe or multiple problems with these elements. ${ }^{16}$ Data Synthesis and Analyses

All studies were qualitatively synthesized and comprehensively presented in tables depicting study characteristics and main findings. Meta-analysis to obtain a summary relative risk estimate was not supported because of the observational design of all included studies with reporting of unadjusted results, the high number of single-arm cohorts, and the large clinical heterogeneity across studies. We calculated pooled incidence of venous thromboembolism, major bleeding, and 
any bleeding in procedures with and without bridging using a logistic-normal random-effects model. ${ }^{17}$ One study used propensity score matching and weighting to compare outcomes in patients with and without bridging; this resulted in some non-integer numbers of outcome events in the nonbridging group, which were rounded to the next integer to calculate pooled incidences. In a sensitivity analysis, we rounded in the other direction. We also conducted pre-specified sensitivity analyses excluding conference abstracts or small studies ( $<100$ procedures). Additional (not prespecified) sensitivity analyses were conducted: 1) excluding studies that did not specifically report outcomes for patients with prior venous thromboembolism, but could be included because no study patient experienced an outcome event, and 2) excluding a study ${ }^{18}$ that used propensity score matching and weighting to equalize the number of patients in the exposure groups.

Predefined subgroup analyses were conducted according to baseline thromboembolic risk and heparin dose used (therapeutic vs. prophylactic). All analyses were performed with Stata 14 (Stata, College Station, TX, USA).

Two investigators (C.B. and M.C. F.) rated the overall quality of evidence for thromboembolic and bleeding outcomes using the Grading of Recommendations Assessment, Development and Evaluation (GRADE) methodology. ${ }^{19}$ 


\section{Results}

Our search yielded 4,349 records after removal of duplicates. We excluded 4,110 records based on title and abstract and then assessed 239 full texts for eligibility, of which 28 studies met our inclusion criteria (Figure 1). Included studies reported results of overall 6,915 procedures, and individual study size varied between 10 and 2670 procedures (Supplemental Table 1).

Of all included studies, 19 were prospective and 9 retrospective cohort studies, and none of them was a randomized trial comparing bridging and VKA interruption without bridging. Study characteristics are shown in Table 1 and Supplemental Table 1. Two records were conference abstracts, and 26 were published full text articles. All but 5 studies enrolled patients with different indications for anticoagulation including atrial fibrillation and mechanical heart valves, and among those we extracted only the specific data on patients with previous venous thromboembolism. Thus, specific information on demographics for this subgroup was mostly missing. Baseline thromboembolic risk was assessed in 21 studies using varying risk classifications schemes. Most studies included patients at any thromboembolic risk $(n=15)$, while 1 included only low risk and 5 only moderate to high risk patients. The decision to administer bridging anticoagulation was at the discretion of the provider in 11 studies and based on assessment of baseline thromboembolic risk in 6 studies; in 5 studies, all patients requiring VKA interruption received bridging. Procedure types were reported in all but 1 study.

Bridging strategies implemented in the different studies varied substantially (Table 2 and Supplemental Table 2). Most of the studies $(n=22)$ defined bridging as administration of short-acting anticoagulants in both the pre- and postprocedural periods, while 2 studies also considered bridging that was administered in the preprocedural and 4 in the postprocedural periods only.

Overall quality of included studies was low (Supplemental Table 3). Only 8 studies compared outcomes in bridging and non-bridging groups, while the remaining were single-arm studies. All 
studies reported results that were unadjusted for potential confounding except for Sjögren et al., ${ }^{18}$ where propensity score matching was used.

\section{Risk of Venous Thromboembolism}

All but one ${ }^{20}$ study reported venous thromboembolism outcomes in overall 6886 procedures. Over a follow-up duration that varied from the time of postprocedural INR normalization to 180 days in the different studies, incidence of perioperative venous thromboembolism ranged from $0 \%$ to $4.4 \%$ with bridging (pooled incidence $0.7 \%, 95 \%$ confidence interval $[\mathrm{Cl}] 0.4-1.2 \%$ ) and from $0 \%$ to $2 \%$ without bridging (pooled incidence $0.5 \%, 95 \% \mathrm{Cl} 0.3-0.8 \%$; Tables 3 and 4).

The pooled incidence of venous thromboembolism in bridging and non-bridging groups remained similar in sensitivity analyses (Table 4). Among patients with high thromboembolic risk, we found a similar pooled incidence of perioperative venous thromboembolism events with bridging (pooled incidence $0.8 \%, 95 \% \mathrm{Cl}$ 0.3-2.5\%). Only 1 study $y^{7}$ reported venous thromboembolism outcomes in high risk patients without bridging, and found 0 events in 21 procedures (Table 4). Incidence of venous thromboembolism was similar with therapeutic LMWH doses compared to prophylactic doses (pooled incidence $0.9 \%$ [95\% $\mathrm{Cl} 0.4-2.1 \%]$ and $1.4 \%$ [95\% $\mathrm{Cl} 0.5-4.4 \%]$, respectively), but the number of studies included in this subgroup analysis was limited (Table 4).

\section{Risk of Bleeding}

Data on major bleeding or any bleeding were available in 15 and 18 studies, respectively (Tables 3 and 4). Incidence of major bleeding as reported in included studies varied between $0 \%$ and $5.6 \%$ for patients with bridging (pooled incidence $1.8 \%, 95 \% \mathrm{Cl} 1.2-2.5 \%$ ), while it was generally lower in patients without bridging, ranging from $0 \%$ to $1.6 \%$ (pooled incidence $0.4 \%, 95 \% \mathrm{Cl} 0.1$ 1.5\%; Tables 3 and 4). Results were similar in sensitivity analyses (Table 4). Therapeutic LMWH 
doses resulted in a similar pooled incidence of major bleeding compared to prophylactic doses (2.6\% [95\% $\mathrm{Cl} 1.4-4.7 \%]$ and $2.1 \%$ [95\% $\mathrm{Cl} 0.8-5.5 \%])$, but the number of studies was low.

Incidence of any major and non-major bleeding differed even more considerably between the bridging and non-bridging groups, with a pooled incidence of $3.9 \%(95 \% \mathrm{Cl} 2.0-7.4 \%)$ and $0.4 \%$ (95\% $\mathrm{Cl} 0.1-1.7 \%)$, respectively (Table 3 and 4 ).

\section{Quality of Overall Evidence}

The quality of the overall body of evidence for the association of periprocedural bridging with venous thromboembolism, major bleeding and any bleeding was very low (Supplemental Table 4). All included studies had an observational design with a very high risk of bias. Also, we assumed publication bias to be substantial for all outcomes, because some studies that did not separately report outcomes for our specific population of interest could not be included in our systematic review (Figure 1), and a search in clinical trial registries yielded two studies without published results that potentially met inclusion criteria. 


\section{Discussion}

This systematic review showed that periprocedural bridging in patients with previous venous thromboembolism considerably increases bleeding risk compared to VKA interruption without bridging, without resulting in differences of venous thromboembolic outcomes. Our results suggest that most venous thromboembolism patients will not benefit from bridging. However, the quality of the available evidence on the risks and benefits of periprocedural bridging in this population is low.

Our results show substantial differences in the definition and management of periprocedural bridging across studies. However, no specific bridging strategy or dosing regimen has proven to be superior. ${ }^{4}$ To date, no randomized study has shown a clear benefit of periprocedural bridging for patients on long-term anticoagulants, while the bulk of available data suggests an increased bleeding risk with bridging. A recent randomized trial found that foregoing bridging was not associated with an increased risk of arterial thromboembolic events but conferred a significant reduction in major bleeding in patients with atrial fibrillation requiring periprocedural warfarin interruption. ${ }^{6}$ Another trial comparing bridging with continued anticoagulation in patients undergoing cardiac device surgery similarly found a 3- to 4-fold higher bleeding risk with bridging. ${ }^{23}$ A systematic review that assessed periprocedural bridging in patients with any indication for anticoagulation concluded that overall and major bleeding was increased in patients with bridging compared to those without, while the risk of thromboembolism did not differ. ${ }^{5}$ However, the low quality of included studies precluded firm conclusions about risks and benefits of bridging particularly for high risk patients, similar to our study. No previous or ongoing trial investigated bridging in patients with previous venous thromboembolism.

Evaluation of patient- and procedure-related risk factors for thromboembolism and bleeding as well as estimation of clinical consequences of these potential adverse events is needed to determine the optimal perioperative anticoagulation management in patients on chronic VKA therapy. ${ }^{43}$ An increasing evidence base suggests that VKAs can be safely continued in a number of 
procedures with low bleeding risk..$^{6,22,23,44}$ More uncertainty exists about periprocedural management strategies in non-minimal bleeding risk procedures, where anticoagulation interruption is needed. While arterial thromboembolic events in patients with mechanical heart valves or atrial fibrillation are related to a substantial $15-70 \%$ risk of disability and death which outweighs mortality risks of major bleeding events 2 to 10 -fold, ${ }^{43,45,46}$ the case-fatality of recurrent venous thromboembolism (5-13\%) and major bleeding events (8-10\%) are more similar. ${ }^{43,47}$ Therefore, the number of major bleeding events that would theoretically be acceptable to prevent one thromboembolic event is substantially lower for patients with previous venous thromboembolism compared to patients anticoagulated for prevention of arterial thromboembolic events, so the threshold to provide treatments that increase the risk of major bleeding should be higher for venous thromboembolism patients. Our results suggest that bridging exposes these patients to a markedly higher bleeding risk and should therefore not be used if thromboembolic risk is low or moderate. Based on the available evidence, admittedly of low quality, a potential benefit of bridging has not been established even in patients at high thromboembolic risk.

Periprocedural bridging continues to be overused in patients with previous venous thromboembolism, mainly because of overestimation of thromboembolic risk, ${ }^{7,48}$ reflecting the uncertainty about the role of bridging and the assessment of baseline thromboembolic risk. Efforts to standardize anticoagulation management in the periprocedural setting and high quality studies to further clarify the efficacy and safety of bridging in patients at high risk of venous thromboembolism are needed to optimize their care. Although VKAs continue to be the most frequently prescribed oral anticoagulants, ${ }^{2}$ the role of bridging, if any, will further diminish with the increased use of DOACs. ${ }^{4,49}$ The shorter half-life of DOACs, which limits the duration of preprocedural anticoagulation interruption, and their rapid time-to-onset obviate the need of periprocedural bridging. ${ }^{4,43,49}$ Only few observational studies and substudies of randomized trials investigated periprocedural management strategies in patients on DOACs, and did not find a benefit of bridging in this population. ${ }^{50,51}$ 
To our knowledge, this is the first study systematically assessing available literature on the risks and benefits of periprocedural bridging in the specific population of patients with previous venous thromboembolism. Another strength of this study includes the rigorous search for available data, without language restriction and with consideration of unpublished articles.

The results of our systematic review need to be interpreted in the context of several limitations. First, overall quality of included studies was low: all included studies were nonrandomized and many of them lacked a comparison group. Second, most studies included a heterogeneous population of patients at high and low thromboembolic risk and procedures at varying degrees of bleeding risk, yielding difficult to interpret results that are likely affected by confounding by indication, as patients at high thromboembolic risk might be more likely to receive bridging compared to non-high risk patients. Third, some studies did not specifically report outcomes for patients with previous venous thromboembolism and could thus not be included in our systematic review (Figure 1), potentially resulting in publication bias. Fourth, follow-up duration differed between studies, and although we calculated pooled incidences of perioperative outcome events, these incidences might differ if follow-up duration in included studies were more homogeneous. Finally, the definition of major bleeding and ascertainment of thromboembolic events was not uniform across studies, which may have limited the reliable estimation of pooled outcome incidences.

In conclusion, our systematic review showed that patients at low and moderate thromboembolic risk do not benefit from periprocedural bridging because of a considerably increased risk of bleeding associated with bridging compared to VKA interruption without bridging, while the risk of periprocedural thromboembolic events was similar with or without bridging. 


\section{Acknowledgments}

We gratefully acknowledge Isabel Elaine Allen for her advice concerning the methodology and statistical analyses of the paper. We acknowledge Yumiko Abe-Jones and Michael Hurley for their help with translating articles, and James D. Douketis for the critical review of the manuscript and his valuable input. 


\section{Sources of Funding}

This study was supported by the National Heart, Lung, and Blood Institute (Grant R01HL103820 and 1K24HL141354). C. Baumgartner's work was supported by a grant from the Swiss National Science Foundation (P2BEP3_165409) and a grant from the Gottfried and Julia Bangerter-Rhyner Foundation.

\section{Role of the Sponsor}

The sponsor had no role in in the design and conduct of the study, in the collection, management, analysis, or interpretation of the data, or the preparation, review, or approval of the manuscript. 


\section{Disclosures}

None.

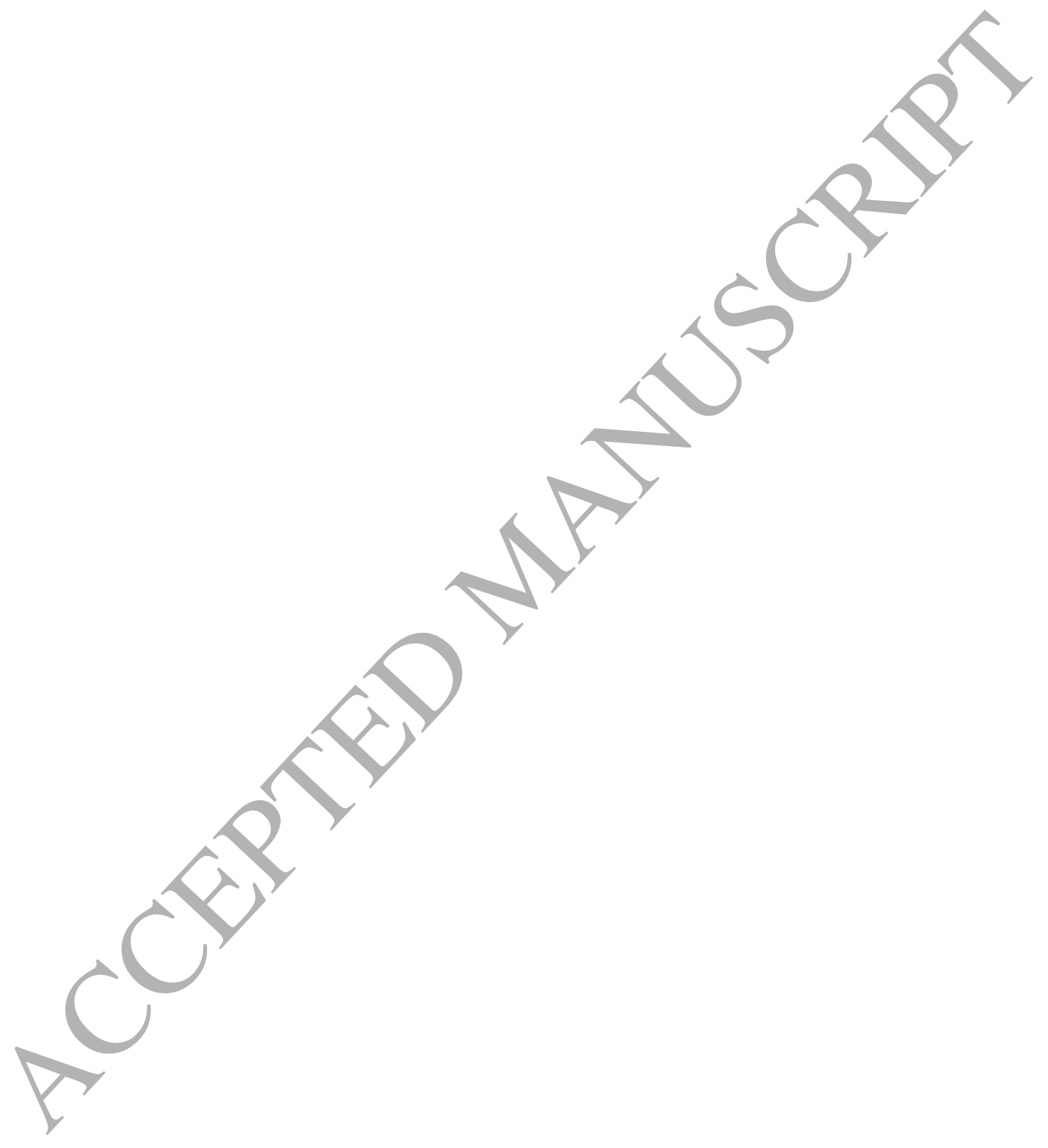




\section{Author Contributions}

All authors participated in the research and preparation of the manuscript.

Study concept and design: Baumgartner, Fang.

Data acquisition: Baumgartner, de Kouchkovsky, Whitaker.

Data analysis and interpretation: Baumgartner, de Kouchkovsky, Fang.

Drafting the manuscript: Baumgartner, Fang.

Critical revision of the manuscript for important intellectual content: Baumgartner, de Kouchkovsky, Whitaker, Fang.

Statistical analyses: Baumgartner.

Study supervision: Fang. 


\section{References}

1. Douketis JD, Spyropoulos AC, Spencer FA, Mayr M, Jaffer AK, Eckman MH, Dunn AS, Kunz R and American College of Chest P. Perioperative management of antithrombotic therapy:

Antithrombotic Therapy and Prevention of Thrombosis, 9th ed: American College of Chest Physicians Evidence-Based Clinical Practice Guidelines. Chest. 2012;141:e326S-350S.

2. Medical Expenditure Panel Survey (MEPS) 2005-2015. Agency for Healthcare Research and Quality (AHRQ), Rockville, MD. ClinCalc DrugStats Database version 18.0. http://clincalc.com/DrugStats/Top300Drugs.aspx, accessed April 11, 2018.

3. Lippi G, Mattiuzzi C, Cervellin G and Favaloro EJ. Direct oral anticoagulants: analysis of worldwide use and popularity using Google Trends. Annals of translational medicine. 2017;5:322.

4. Doherty JU, Gluckman TJ, Hucker WJ, Januzzi JL, Jr., Ortel TL, Saxonhouse SJ and Spinler SA. 2017 ACC Expert Consensus Decision Pathway for Periprocedural Management of Anticoagulation in Patients With Nonvalvular Atrial Fibrillation: A Report of the American College of Cardiology Clinical Expert Consensus Document Task Force. J Am Coll Cardiol. 2017;69:871-898.

5. Siegal D, Yudin J, Kaatz S, Douketis JD, Lim W and Spyropoulos AC. Periprocedural heparin bridging in patients receiving vitamin K antagonists: systematic review and meta-analysis of bleeding and thromboembolic rates. Circulation. 2012;126:1630-1639.

6. Douketis JD, Spyropoulos AC, Kaatz S, Becker RC, Caprini JA, Dunn AS, Garcia DA, Jacobson A, Jaffer AK, Kong DF, Schulman S, Turpie AG, Hasselblad V and Ortel TL. Perioperative Bridging Anticoagulation in Patients with Atrial Fibrillation. N Engl J Med. 2015;373:823-833.

7. Clark NP, Witt DM, Davies LE, Saito EM, McCool KH, Douketis JD, Metz KR and Delate T. Bleeding, Recurrent Venous Thromboembolism, and Mortality Risks During Warfarin Interruption for Invasive Procedures. JAMA Intern Med. 2015;175:1163-1168.

8. Moher D, Liberati A, Tetzlaff J and Altman DG. Preferred reporting items for systematic reviews and meta-analyses: the PRISMA statement. BMJ. 2009;339:b2535. 
9. Dunn AS and Turpie AG. Perioperative management of patients receiving oral anticoagulants: a systematic review. Arch Intern Med. 2003;163:901-908.

10. Spyropoulos AC, Douketis JD, Gerotziafas G, Kaatz S, Ortel TL and Schulman S. Periprocedural antithrombotic and bridging therapy: recommendations for standardized reporting in patients with arterial indications for chronic oral anticoagulant therapy. J Thromb Haemost. 2012;10:692-694. 11. Selby K, Baumgartner C, Levin TR, Doubeni CA, Zauber AG, Schottinger J, Jensen CD, Lee JK and Corley DA. Interventions to Improve Follow-up of Positive Results on Fecal Blood Tests: A Systematic Review. Ann Intern Med. 2017;167:565-575.

12. Klamroth R, Gottstein S, Essers E and Landgraf H. Bridging with enoxaparin using a halftherapeutic dose regimen: safety and efficacy. Vasa. 2010;39:243-248.

13. McBane RD, Wysokinski WE, Daniels PR, Litin SC, Slusser J, Hodge DO, Dowling NF and Heit JA. Periprocedural anticoagulation management of patients with venous thromboembolism. Arterioscler Thromb Vasc Biol. 2010;30:442-448.

14. Pengo V, Cucchini U, Denas G, Erba N, Guazzaloca G, La Rosa L, De Micheli V, Testa S, Frontoni R, Prisco D, Nante G, Iliceto S, Italian Federation of Centers for the Diagnosis of T and Management of Antithrombotic T. Standardized low-molecular-weight heparin bridging regimen in outpatients on oral anticoagulants undergoing invasive procedure or surgery: an inception cohort management study. Circulation. 2009;119:2920-2927.

15. Guyatt GH, Norris SL, Schulman S, Hirsh J, Eckman MH, AkI EA, Crowther M, Vandvik PO, Eikelboom JW, McDonagh MS, Lewis SZ, Gutterman DD, Cook DJ and Schunemann HJ. Methodology for the development of antithrombotic therapy and prevention of thrombosis guidelines:

Antithrombotic Therapy and Prevention of Thrombosis, 9th ed: American College of Chest Physicians Evidence-Based Clinical Practice Guidelines. Chest. 2012;141:53S-70S.

16. Guyatt GH, Oxman AD, Vist G, Kunz R, Brozek J, Alonso-Coello P, Montori V, Akl EA, Djulbegovic B, Falck-Ytter Y, Norris SL, Williams JW, Jr., Atkins D, Meerpohl J and Schunemann HJ. 
GRADE guidelines: 4. Rating the quality of evidence--study limitations (risk of bias). J Clin Epidemiol. 2011;64:407-415.

17. Nyaga VN, Arbyn M and Aerts M. Metaprop: a Stata command to perform meta-analysis of binomial data. Arch Public Health. 2014;72:39.

18. Sjogren V, Grzymala-Lubanski B, Renlund H, Svensson PJ and Sjalander A. Safety and Efficacy of Bridging With Low-Molecular-Weight Heparin During Temporary Interruptions of Warfarin: A Register-Based Cohort Study. Clin Appl Thromb Hemost. 2017;23:961-966.

19. Guyatt G, Oxman AD, AkI EA, Kunz R, Vist G, Brozek J, Norris S, Falck-Ytter Y, Glasziou P, DeBeer H, Jaeschke R, Rind D, Meerpohl J, Dahm P and Schunemann HJ.GRADE guidelines: 1. Introduction-GRADE evidence profiles and summary of findings tables. J Clin Epidemiol. 2011;64:383394.

20. Douketis JD, Woods K, Foster GA and Crowther MA. Bridging anticoagulation with lowmolecular-weight heparin after interruption of warfarin therapy is associated with a residual anticoagulant effect prior to surgery. Thromb Haemost. 2005;94:528-531.

21. Ahmed I, Gertner E, Nelson WB, House CM, Dahiya R, Anderson CP, Benditt DG and Zhu DW. Continuing warfarin therapy is superior to interrupting warfarin with or without bridging anticoagulation therapy in patients undergoing pacemaker and defibrillator implantation. Heart Rhythm. 2010;7:745-749.

22. Bajkin BV, Popovic SL and Selakovic SD. Randomized, prospective trial comparing bridging therapy using low-molecular-weight heparin with maintenance of oral anticoagulation during extraction of teeth. J Oral Maxillofac Surg. 2009;67:990-995.

23. Birnie DH, Healey JS and Essebag V. Device surgery without interruption of anticoagulation. N Engl J Med. 2013;369:1571-1572.

24. Breen DT, Chavalertsakul N, Paul E, Gruen RL and Serpell J. Perioperative complications in patients on low-molecular-weight heparin bridging therapy. ANZ J Surg. 2016;86:167-172. 
25. Burbury KL, Milner A, Snooks B, Jupe D and Westerman DA. Short-term warfarin reversal for elective surgery--using low-dose intravenous vitamin $\mathrm{K}$ : safe, reliable and convenient* ${ }^{*} \mathrm{Br} \mathrm{J}$ Haematol. 2011;154:626-634.

26. Dunn AS, Spyropoulos AC and Turpie AG. Bridging therapy in patients on long-term oral anticoagulants who require surgery: the Prospective Peri-operative Enoxaparin Cohort Trial (PROSPECT). J Thromb Haemost. 2007;5:2211-2218.

27. Eisele R, Melzer N, Englert C, Bramlage P and Spannagl M. Bridging with the Low molecular weight heparin certoparin in patients requiring temporary discontinuation of oral anticoagulation the non-interventional, retrospective REMEMBER study. Thromb Res. 2012;130:788-792.

28. Fernandez ON and Mavri A. Evaluation of periprocedural anticoagulation management in patients on long term oral anticoagulants. J Thromb Haemost. 2009;7:1071-1072.

29. Garcia DA, Regan S, Henault LE, Upadhyay A, Baker J, Othman M and Hylek EM. Risk of thromboembolism with short-term interruption of warfarin therapy. Arch Intern Med. 2008;168:6369.

30. Hammerstingl C, Omran H, Tripp C and Poetzsch B. How useful is determination of antifactor Xa activity to guide bridging therapy with enoxaparin? A pilot study. Thromb Haemost. 2009;101:325-332.

31. Hwang HG, Koo SM, Uh ST and Kim YK. The Perioperative Management of Antithrombotic Therapies Using Enoxaparin. J Korean Med Sci. 2017;32:942-947.

32. Jaffer AK, Ahmed M, Brotman DJ, Bragg L, Seshadri N, Qadeer MA and Klein A. Lowmolecular-weight-heparins as periprocedural anticoagulation for patients on long-term warfarin therapy: a standardized bridging therapy protocol. J Thromb Thrombolysis. 2005;20:11-16.

33. Majluf Cruz A, Moreno-Hernandez M, Garcia-Chavez J, Vela-Ojeda J, Hernandez-Juarez J and Coria-Ramirez E. Bridging with rivaroxaban in patients with chronic use of vitamin $\mathrm{K}$ antagonists. Eur Heart J. 2011;32:414. 
34. Malato A, Saccullo G, Lo Coco L, Caramazza D, Abbene I, Pizzo G, Casuccio A and Siragusa S. Patients requiring interruption of long-term oral anticoagulant therapy: the use of fixed subtherapeutic doses of low-molecular-weight heparin. J Thromb Haemost. 2010;8:107-113.

35. Saccullo G, Malato A, Raso S, Santoro M, Zammit V, Casuccio A and Siragusa S. Cancer patients requiring interruption of long-term warfarin because of surgery or chemotherapy induced thrombocytopenia: the use of fixed sub-therapeutic doses of low-molecular weight heparin. Am J Hematol. 2012;87:388-391.

36. Santamaria A, Ugarriza A, Munoz C, De Diego I, Lopez-Chulia F, Benet C, Martinez-Gonzalez J, Gomez N, Pina E, Ortin X, Marco P, Roncales FJ and Fontcuberta J. Bemiparin verşus unfractionated heparin as bridging therapy in the perioperative management of patients on vitamin $\mathrm{K}$ antagonists: the BERTA study. Clin Drug Investig. 2013;33:921-928.

37. Skeith L, Taylor J, Lazo-Langner A and Kovacs MJ. Conservative perioperative anticoagulation management in patients with chronic venous thromboembolic disease: a cohort study. J Thromb Haemost. 2012;10:2298-2304.

38. Spyropoulos AC, Jenkins P and Bornikova L. A disease management protocol for outpatient perioperative bridge therapy with enoxaparin in patients requiring temporary interruption of longterm oral anticoagulation. Pharmacotherapy. 2004;24:649-658.

39. Spyropoulos AC, Turpie AG, Dunn AS, Spandorfer J, Douketis J, Jacobson A, Frost FJ and Investigators R. Clinical outcomes with unfractionated heparin or low-molecular-weight heparin as bridging therapy in patients on long-term oral anticoagulants: the REGIMEN registry. $J$ Thromb Haemost. 2006;4:1246-1252.

40. Wilson SJ-A, Morgan J, Gray L, Newman V and Anderson DR. A model for perioperative outpatient management of anticoagulation in high-risk patients: an evaluation of effectiveness and safety. The Canadian Journal of Hospital Pharmacy. 2001;54.

41. Wiszniewski A, Szopinski P, Ratajczak J, Bilski R and Bykowska K. Perioperative bridging therapy with low molecular weight heparin for patients with inherited thrombophilia and 
antiphospholipid syndrome on long-term acenokumarol therapy. Blood Coagul Fibrinolysis.

2011;22:34-39.

42. Constans M, Santamaria A, Mateo J, Pujol N, Souto JC and Fontcuberta J. Low-molecularweight heparin as bridging therapy during interruption of oral anticoagulation in patients undergoing colonoscopy or gastroscopy. Int J Clin Pract. 2007;61:212-217.

43. Spyropoulos AC, AI-Badri A, Sherwood MW and Douketis JD. Periprocedural management of patients receiving a vitamin $\mathrm{K}$ antagonist or a direct oral anticoagulant requiring an elective procedure or surgery. J Thromb Haemost. 2016;14:875-885.

44. Kowalewski M, Suwalski P, Raffa GM, Slomka A, Kowalkowska ME, Szwed KA, Borkowska A, Kowalewski J, Malvindi PG, Undas A, Windyga J, Pawliszak W, Anisimowicz L, Carrel T, Paparella D and Lip GY. Meta-analysis of uninterrupted as compared to interrupted oral anticoagulation with or without bridging in patients undergoing coronary angiography with or without percutaneous coronary intervention. Int J Cardiol. 2016;223:186-194.

45. Longstreth WT, Jr., Bernick C, Fitzpatrick A, Cushman M, Knepper L, Lima J and Furberg CD. Frequency and predictors of stroke death in 5,888 participants in the Cardiovascular Health Study. Neurology. 2001;56:368-375.

46. Durrleman N, Pellerin M, Bouchard D, Hebert $\mathrm{Y}$, Cartier R, Perrault LP, Basmadjian A and Carrier M. Prosthetic valve thrombosis: twenty-year experience at the Montreal Heart Institute. J Thorac Cardiovasc Surg. 2004;127:1388-1392.

47. Carrier M, Le Gal G, Wells PS and Rodger MA. Systematic review: case-fatality rates of recurrent venous thromboembolism and major bleeding events among patients treated for venous thromboembolism. Ann Intern Med. 2010;152:578-589.

48. Barnes GD, Kurlander J, Haymart B, Kaatz S, Saini S and Froehlich JB. Bridging Anticoagulation Before Colonoscopy: Results of a Multispecialty Clinician Survey. JAMA Cardiol. 2016;1:1076-1077. 
49. Barnes GD and Mouland E. Peri-Procedural Management of Oral Anticoagulants in the DOAC Era. Prog Cardiovasc Dis. 2018.

50. Beyer-Westendorf J, Gelbricht V, Forster K, Ebertz F, Kohler C, Werth S, Kuhlisch E, Stange T, Thieme C, Daschkow K and Weiss N. Peri-interventional management of novel oral anticoagulants in daily care: results from the prospective Dresden NOAC registry. Eur Heart J. 2014;35:1888-1896.

51. Sherwood MW, Douketis JD, Patel MR, Piccini JP, Hellkamp AS, Lokhnygina Y, Spyropoulos AC, Hankey GJ, Singer DE, Nessel CC, Mahaffey KW, Fox KA, Califf RM and Becker RC. Outcomes of temporary interruption of rivaroxaban compared with warfarin in patients with nonvalvular atrial fibrillation: results from the rivaroxaban once daily, oral, direct factor Xa inhibition compared with vitamin $\mathrm{K}$ antagonism for prevention of stroke and embolism trial in atrial fibrillation (ROCKET AF).

Circulation. 2014;129:1850-1859. 
Figure

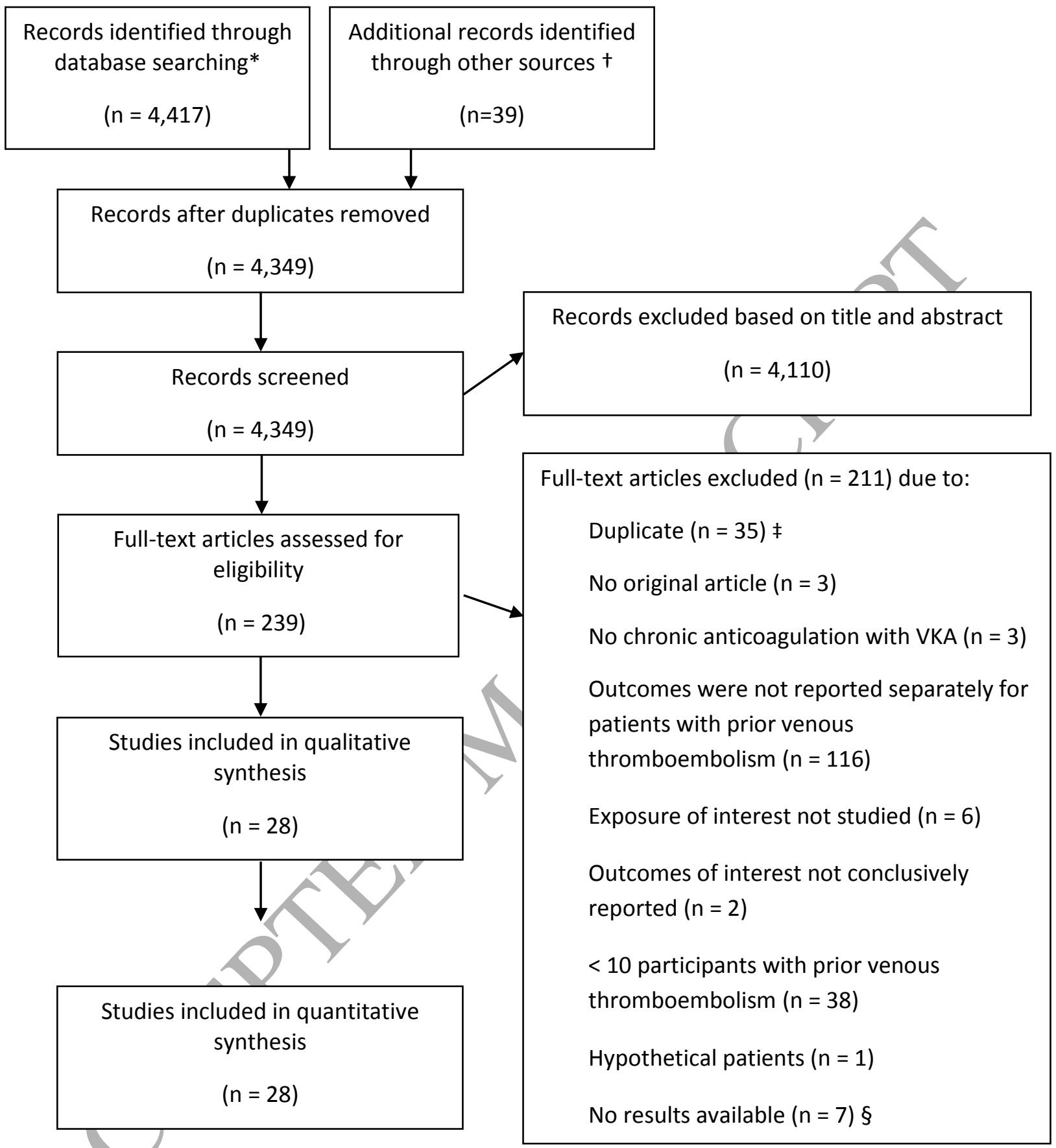


Figure Legend. Study flow diagram. Studies evaluated for inclusion, adapted from PRISMA Statement Flow Diagram. ${ }^{8}$ Abbreviations: VKA, vitamin K antagonist.

* Until December 7, 2017

+ identified through searching of bibliographies and clinical trial databases

‡ refers to duplicate publication (e.g. conference abstract) or studying the same population as another publication

$\S$ because abstract/publication was not available and results could not be obtained from authors, or study was still ongoing 
Table 1. Characteristics of Included Studies

\begin{tabular}{|c|c|c|}
\hline Characteristic & & Studies, n (\%) \\
\hline \multicolumn{3}{|l|}{ Design and Setting } \\
\hline \multirow[t]{4}{*}{ Study design } & Randomized controlled trial & $0^{*}$ \\
\hline & Cohort, prospective & $19(68)$ \\
\hline & Cohort, retrospective & $9(32)$ \\
\hline & Single-arm studies & $20(71)+$ \\
\hline \multirow[t]{2}{*}{ Year of Publication } & Before 2010 & $12(43)$ \\
\hline & 2010 and later & $16(57)$ \\
\hline \multirow[t]{2}{*}{ Publication Type } & Full text article & $26(93)$ \\
\hline & Conference abstract & $2(7)$ \\
\hline \multirow[t]{3}{*}{ Study sponsors } & Industry & $5(18)$ \\
\hline & Non-profit & $7(25)$ \\
\hline & Not reported & $16(57)$ \\
\hline \multirow[t]{6}{*}{ Geographical region } & North America & $11(39)$ \\
\hline & South America & $1(4)$ \\
\hline & Europe & $11(39)$ \\
\hline & Asia & $1(4)$ \\
\hline & Australia & $2(7)$ \\
\hline & Not reported & $2(7)$ \\
\hline \multirow[t]{3}{*}{ Number of study sites } & Single center & $14(50)$ \\
\hline & Multicenter & $10(36)$ \\
\hline & Not reported & $4(14)$ \\
\hline Treatment setting & Outpatients only & $4(14)$ \\
\hline \multicolumn{3}{|l|}{ Population } \\
\hline \multirow[t]{3}{*}{$\%$ of patients with previous venous thromboembolism } & $0-19 \%$ & $10(36)$ \\
\hline & $20-99 \%$ & $13(46)$ \\
\hline & $100 \%$ & $5(18)$ \\
\hline \multirow[t]{4}{*}{ Thromboembolic risk of included patients } & Any risk & $15(54)$ \\
\hline & Only low risk & $1(4)$ \\
\hline & Only moderate to high risk & $5(18)$ \\
\hline & No risk stratification performed & $7(25)$ \\
\hline \multirow[t]{5}{*}{ Reason for VKA interruption } & Antiarrhythmic device surgery & $2(7)$ \\
\hline & Dental procedures & $1(4)$ \\
\hline & Only minor surgeries or procedures & $4(14)$ \\
\hline & Minor and major surgeries/procedures & $20(71)$ \\
\hline & Unclear & $1(4)$ \\
\hline \multirow[t]{6}{*}{ Indication for bridging } & At the discretion of the provider & $11(39)$ \\
\hline & Strictly based on thromboembolic risk & $6(21)$ \\
\hline & All patients requiring VKA interruption & $5(18)$ \\
\hline & Random assignment & $2(7) \ddagger$ \\
\hline & Only inpatients & $1(4)$ \\
\hline & unclear & $3(11)$ \\
\hline
\end{tabular}

Abbreviations: INR, international normalized ratio; VKA, vitamin K antagonist.

*three studies were designed as randomized controlled trials comparing bridging to continued VKA

or comparing two different bridging strategies. We considered these studies as prospective cohorts

for our study because none of these trials compared bridging and VKA interruption without bridging.

† among all prospective and retrospective cohort studies 
‡ patients were randomly assigned to bridging or continuation of VKA in two studies, but none used random assignment to bridging vs. VKA interruption without bridging

$\S$ Some studies implemented multiple strategies 
Table 2. Periprocedural Anticoagulation Management

\begin{tabular}{|c|c|c|}
\hline Management Strategy* & & Studies, n (\%) \\
\hline \multirow[t]{4}{*}{ Periprocedural Bridging } & Pre- and postprocedural & $22(79)$ \\
\hline & Only preprocedural & $2(7)$ \\
\hline & Only postprocedural & $4(14)$ \\
\hline & Not specified & $4(14)$ \\
\hline \multirow[t]{2}{*}{ Type of bridging anticoagulant } & LMWH & $28(100)$ \\
\hline & Unfractionated heparin & $6(21)$ \\
\hline \multirow[t]{4}{*}{ Dosing of bridging anticoagulant } & Therapeutic & $18(64)$ \\
\hline & Sub-therapeutic & $9(32)$ \\
\hline & Prophylactic & $16(57)$ \\
\hline & Not reported & $1(4)$ \\
\hline \multicolumn{3}{|l|}{ Preprocedural Management } \\
\hline \multirow[t]{4}{*}{ VKA interruption, days } & $\geq 6$ & $7(25)$ \\
\hline & 5 & $19(68)$ \\
\hline & $\leq 4$ & $9(32)$ \\
\hline & not reported & $3(11)$ \\
\hline \multirow[t]{5}{*}{ Last dose of LMWH, hours } & $<12$ & $1(4)$ \\
\hline & $12-23$ & $13(46)$ \\
\hline & $\geq 24$ & $7(25)$ \\
\hline & NA (only postop bridging) & $2(7)$ \\
\hline & Not reported & $6(21)$ \\
\hline \multicolumn{3}{|l|}{ Postprocedural Management } \\
\hline \multirow[t]{3}{*}{ Restart of LMWH, hours } & $0-23$ & $16(57)$ \\
\hline & $\geq 24$ & $7(25)$ \\
\hline & Not specifically reported & $7(25)$ \\
\hline \multirow[t]{4}{*}{ Restart of VKA, hours } & Evening of procedure & $10(36)$ \\
\hline & Day after procedure & $18(64)$ \\
\hline & 2 or more days after procedure & $4(14)$ \\
\hline & Not reported & $6(21)$ \\
\hline \multirow[t]{3}{*}{ Initial dosing of VKA } & Maintenance dose & $9(32)$ \\
\hline & Loading dose & $3(11)$ \\
\hline & Not reported & $16(57)$ \\
\hline \multirow[t]{4}{*}{ Duration of bridging } & Prespecified no. of days & $2(7)$ \\
\hline & Until INR therapeutic & $12(43)$ \\
\hline & Until INR therapeutic on 2 consecutive days & $5(18)$ \\
\hline & Not reported & $9(32)$ \\
\hline
\end{tabular}

Abbreviations: INR, international normalized ratio; LMWH, low molecular weight heparin; VKA,

vitamin $\mathrm{K}$ antagonist.

* Some studies implemented multiple strategies 
Table 3. Venous Thromboembolism and Bleeding Outcomes

\begin{tabular}{|c|c|c|c|c|c|}
\hline \multirow[b]{2}{*}{ Study } & \multirow[b]{2}{*}{$\begin{array}{l}\text { Follow-up } \\
\text { Duration }\end{array}$} & \multicolumn{3}{|c|}{ Bridging } & \multirow[b]{2}{*}{$\begin{array}{c}\text { Venous } \\
\text { thromboembolism/ } \\
\text { Procedures, } \mathrm{n}(\%)\end{array}$} \\
\hline & & $\begin{array}{l}\text { Venous } \\
\text { thromboembolism/ } \\
\text { Procedures, } \mathrm{n}(\%)\end{array}$ & $\begin{array}{l}\text { Major Bleeding/ } \\
\text { Procedures, n (\%) }\end{array}$ & $\begin{array}{l}\text { Any Bleeding ||/ } \\
\text { Procedures, n (\%) }\end{array}$ & \\
\hline Ahmed, $2010^{21}$ & 8 weeks & $0 / 12(0)$ & NA & $1 / 12(8.3)$ & $0 / 5(0)$ \\
\hline Bajkin, $2009^{22} *$ & 30d & $0 / 19(0)$ & NA & not clear & - \\
\hline Birnie, $2013^{23} *$ & not clear & $0 / 16(0)$ & NA & not clear & - \\
\hline Breen, $2016^{24}$ & 30d & $0 / 29(0)$ & not clear & $6 / 29(20.7)$ & - \\
\hline Burbury, $2011^{25 *}$ & 6 weeks & - & - & - & $0 / 39(0)$ \\
\hline Clark, $2015^{7}$ & 30d & 0/555 (0) & $12 / 555(2.2)$ & $15 / 555(2.7)$ & $3 / 1257(0.2)$ \\
\hline Constans, $2007^{42} *$ & $90 d$ & $0 / 10(0)$ & not clear & not clear & - \\
\hline Douketis, $2005^{20}$ & until INR 2-3 & NA & $0 / 21(0)$ & $0 / 21(0)$ & - \\
\hline Dunn, $2007^{26}$ & $28 d$ & $1 / 96(1.0)$ & not clear & not clear & - \\
\hline Eisele, $2012^{27} *$ & not clear & $0 / 69(0)$ & NA & not clear & - \\
\hline Fernandez, $2009^{28} *$ & 30d & $0 / 24(0)$ & not clear & not clear & $0 / 14(0)$ \\
\hline Garcia, $2008^{29}$ & $30 d$ & $0 / 22(0)$ & not clear & not clear & 2/179 (1.1) \\
\hline Hammerstingl, $2009^{30} *$ & not clear & $0 / 10(0)$ & $0 / 10(0)$ & $0 / 10(0)$ & - \\
\hline Hwang, $2017^{31} *$ & 30d & $0 / 34(0)$ & not clear & not clear & - \\
\hline Jaffer, $2005^{32}$ & $30 d$ & $0 / 18(0)$ & $1 / 18(5.6)$ & $1 / 18(5.6)$ & - \\
\hline Klamroth, $2010^{12}$ & $28 d$ & $0 / 63(0)$ & $0 / 63(0)+$ & $0 / 63(0)+$ & - \\
\hline Majluf-Cruz, $2011^{33}$ & not clear & $2 / 152(1.3)$ & $4 / 152(2.6)$ & $26 / 152(17.1)$ & - \\
\hline Malato, $2010^{34}$ & 30d & $2 / 45(4.4)$ & $1 / 45(2.2)$ & $1 / 45(2.2)$ & - \\
\hline McBane, $2010^{13}$ & $90 d$ & $4 / 342(1.2)+$ & $9 / 342(2.6)+$ & $24 / 342(7.0)+$ & $3 / 152(2.0)+$ \\
\hline Pengo, $2009^{14}$ & $30 d$ & $2 / 210(1.0)$ & $1 / 210(0.5)+$ & $9 / 210(4.3)+$ & - \\
\hline Saccullo, $2012^{35}$ & $30 d$ & $2 / 52(3.8)$ & not clear & not clear & - \\
\hline Santamaria, $2013^{36} *$ & $90 d$ & $0 / 10(0)$ & not clear & not clear & - \\
\hline Sjögren, $2017^{18}$ & $30 d$ & $10 / 1331(0.8)$ & NA & $10 / 1331(0.8)$ & $5.5 / 1331(0.4) \ddagger$ \\
\hline Skeith, $2012^{37}$ & $90 d$ & $2 / 152(1.3)$ & 2/152 (1.3) & $6 / 152$ (3.9) & $2 / 482(0.4)$ \\
\hline Spyropoulos, $2004^{38}$ & $60 d$ & $0 / 45(0)$ & $0 / 45(0)$ & $2 / 45(4.4)$ & - \\
\hline Spyropoulos, $2006^{39} *$ & $30 d$ & $0 / 22(0) \S$ & not clear & not clear & - \\
\hline Wilson, $2001^{40}$ & $90 d$ & $0 / 26(0)$ & $0 / 26(0)$ & $0 / 26(0)$ & - \\
\hline Wiszniewsky, $2011^{41}$ & $180 d$ & $0 / 63(0)$ & $0 / 63(0)$ & $13 / 63(20.6)$ & - \\
\hline
\end{tabular}

Abbreviations: NR, not available because outcome was not assessed in study.

*these studies did not specifically report venous thromboembolism outcomes by indication for

anticoagulation (i.e. patients with previous venous thromboembolism), but were included because

the number of outcome events was 0 for all indications

† personal communication by the authors

¥ patients not receiving bridging anticoagulation were propensity score matched and weighted to equal the number of patients who received bridging

$\S$ the number of venous thromboembolic events in subgroup of patients with a previous venous thromboembolism could only be identified in the 22 patients who received unfractionated heparin 
II includes major bleeding and any other bleeding outcome that was specifically reported for patients with previous venous thromboembolism

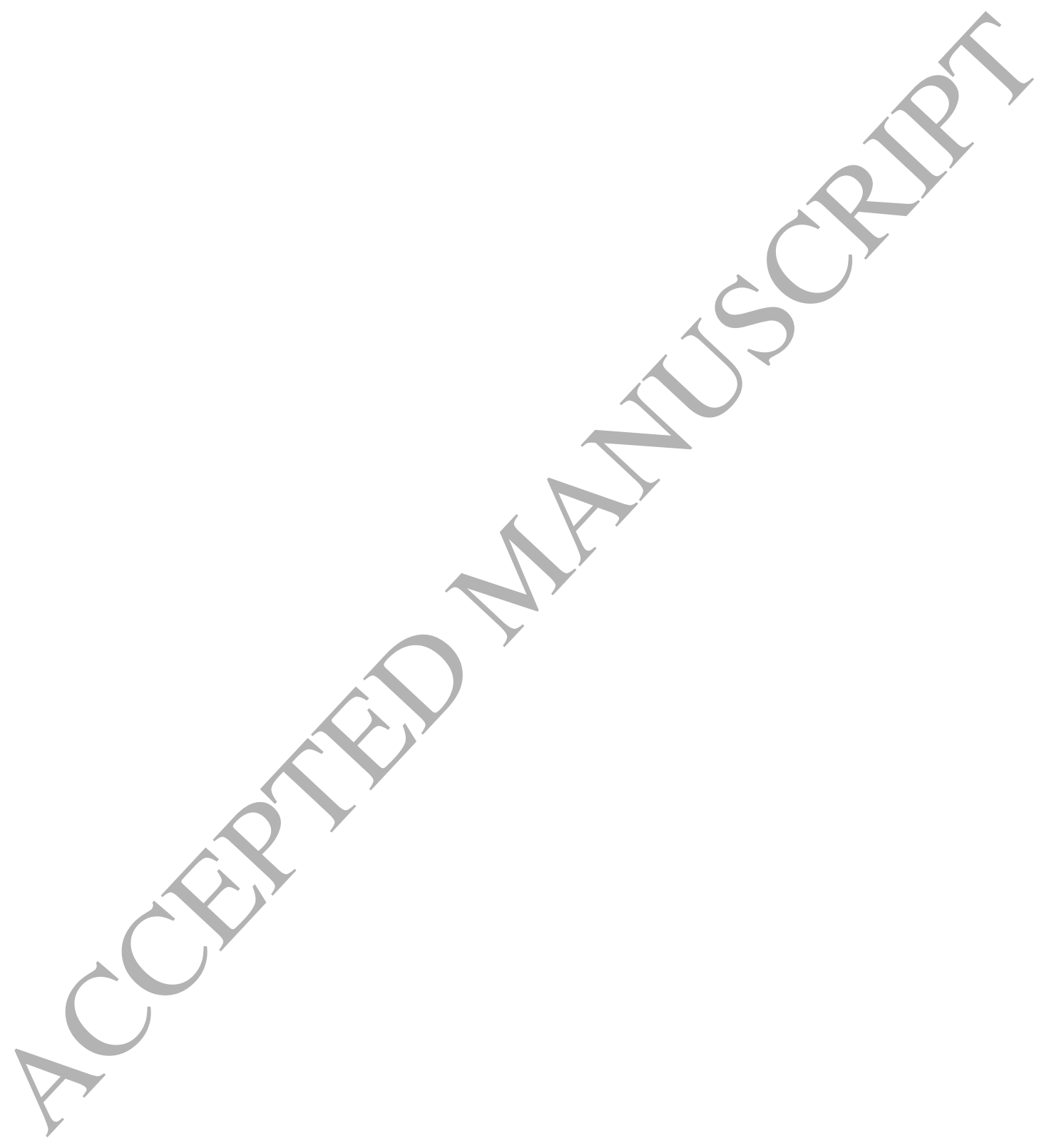


Table 4. Pooled Incidence of Venous Thromboembolism and Bleeding Outcomes

\begin{tabular}{|c|c|c|c|c|c|c|c|c|}
\hline \multirow[b]{2}{*}{ Group } & \multicolumn{2}{|c|}{ Any Outcome } & \multicolumn{3}{|c|}{ Venous Thromboembolism } & \multicolumn{3}{|c|}{ Major Bleeding } \\
\hline & $\begin{array}{c}\text { Studies, } \\
\mathrm{n}\end{array}$ & $\begin{array}{c}\text { Procedures, } \\
\mathbf{n}\end{array}$ & $\begin{array}{c}\text { Studies, } \\
\mathbf{n}\end{array}$ & $\begin{array}{c}\text { Events/ } \\
\text { Procedures, } \\
\mathbf{n}\end{array}$ & $\begin{array}{l}\text { Pooled } \\
\text { incidence, \% } \\
(95 \% \mathrm{Cl})\end{array}$ & $\begin{array}{c}\text { Studies, } \\
\mathrm{n}\end{array}$ & $\begin{array}{c}\text { Events/ } \\
\text { Procedures, } \\
\mathbf{n}\end{array}$ & $\begin{array}{c}\text { Pooled } \\
\text { incidence, } \\
(95 \% \mathrm{Cl})\end{array}$ \\
\hline \multicolumn{9}{|l|}{ Main Analysis } \\
\hline All studies & 28 & $6915+$ & 27 & $40.5 / 6886$ & & 15 & $41 / 3786$ & \\
\hline With bridging & 27 & 3448 & 26 & 25 / 3427 & $0.7(0.4-1.2)$ & 13 & 30 / 1702 & $1.8(1.2-2.5$ \\
\hline Without bridging & 8 & 3459 & 8 & 15.5 / 3459 & $0.5(0.3-0.8) \ddagger$ & 5 & $11 / 2084$ & $0.4(0.1-1.5$ \\
\hline \multicolumn{9}{|l|}{ Sensitivity analyses } \\
\hline $\begin{array}{l}\text { Excluding studies without } \\
\text { specific outcome reporting } \\
\text { for population of interest || }\end{array}$ & 18 & $6648^{+}$ & 17 & 40.5 / 6619 & & & $41 / 3557$ & \\
\hline With bridging & 18 & 3234 & 17 & 25 / 3213 & $0.8(0.5-1.3)$ & 11 & $30 / 1666$ & $1.8(1.3-2.6$ \\
\hline Without bridging & 6 & 3406 & 6 & $15.5 / 3406$ & $0.5(0.3-0.8) \mp$ & 3 & 11 / 1891 & $0.5(0.1-2.0$ \\
\hline $\begin{array}{l}\text { Excluding conference } \\
\text { abstracts }\end{array}$ & 26 & $6725^{+}$ & 25 & 38.5 / 6696 & & 13 & 37 / 3620 & \\
\hline With bridging & 25 & 3272 & 24 & 23 / 3251 & $0.7(0.4-1.2)$ & 12 & $26 / 1550$ & $1.6(0.8-3.2$ \\
\hline Without bridging & 7 & 3445 & 7 & 15.5 / 3445 & $0.5(0.3-0.8) \ddagger$ & 4 & $11 / 2070$ & $0.4(0.1-1.6$ \\
\hline Excluding Sjögren, et al. † & 27 & 4245 & 26 & $25 / 4224$ & & 15 & $41 / 3832$ & \\
\hline With bridging & 26 & 2117 & 25 & 15 / 2096 & $0.6(0.3-1.3)$ & 13 & $30 / 1702$ & $1.8(1.2-2.5$ \\
\hline Without bridging & 7 & 2128 & 7 & $10 / 2128$ & $0.5(0.2-1.2)$ & 5 & $11 / 2084$ & $0.4(0.1-1.5$ \\
\hline $\begin{array}{l}\text { Excluding studies with }<100 \\
\text { procedures }\end{array}$ & 7 & $6173+$ & 7 & $35.5 / 6165$ & & 6 & 39 / 3481 & \\
\hline With bridging & 7 & 2764 & 7 & 20 / 2764 & $0.7(0.4-1.2)$ & 5 & $28 / 1411$ & $2.0(1.4-2.9$ \\
\hline Without bridging & 5 & 3401 & 5 & $15.5 / 3401$ & $0.5(0.3-0.8) \ddagger$ & 4 & $11 / 2070$ & $0.4(0.1-1.6$ \\
\hline \multicolumn{9}{|l|}{ Subgroup analyses } \\
\hline High thromboembolic risk +† & 9 & 394 & 9 & $3 / 394$ & & & & \\
\hline With bridging & 9 & 373 & 9 & $3 / 373$ & $0.8(0.3-2.5)$ & NA & NA & NA \\
\hline Without bridging & 1 & 21 & $1 \Gamma$ & $0 / 21$ & NA & NA & NA & NA \\
\hline \multicolumn{9}{|l|}{ LMWH dose †t } \\
\hline Therapeutic dose & 11 & 981 & 10 & $5 / 580$ & $0.9(0.4-2.1)$ & 4 & $10 / 387$ & $2.6(1.4-4.7$ \\
\hline Prophylactic dose & 6 & 362 & 5 & $3 / 208$ & $1.4(0.5-4.4)$ & 3 & $4 / 188$ & $2.1(0.8-5.5$ \\
\hline
\end{tabular}

* includes major bleeding and any other bleeding outcomes that were specifically reported for

patients with previous venous thromboembolism

† in the study by Sjogren et $\mathrm{al}^{18}{ }^{18}$ procedures in the non-bridging group were propensity score

matched and weighted to equal the number of procedures in the bridging group; therefore, the

number of procedures with bridging and without bridging does not add up to the exact number of

overall procedures

¥ the non-integer number of outcome events ( 5.5 venous thromboembolic events) in the study by

Sjögren et al was rounded to the next integer for this analysis. When rounding down to the next

lower integer, the results were similar (pooled incidence $0.4 \%, 95 \% \mathrm{Cl} 0.3-0.7 \%$ ) 
$\S$ the non-integer number of outcome events ( 2.1 events of any bleeding) in the study by Sjögren et al was rounded to the next integer for this analysis. When rounding up to the next higher integer, the results were similar (pooled incidence $0.5 \%, 95 \% \mathrm{Cl} 0.1-1.8 \%$ ) | some studies did not report results separately for patients with prior venous thromboembolism and could only be included because there were no venous thromboembolism $22,23,25,27,28,30,31,36,39,42$ or bleeding ${ }^{28-30,40}$ outcomes in the overall population. As this might bias our study sample to studies with a low number of outcome events, we excluded these studies for this subgroup analysis.

I the non-integer number of outcome events ( 2.1 events of any bleeding) in the study by Sjögren et al was rounded to the next integer for this analysis. When rounding up to the next higher integer, the results were similar (pooled incidence $0.7 \%, 95 \% \mathrm{Cl} 0.2-2.4 \%$ )

** the non-integer number of outcome events ( 2.1 events of any bleeding) in the study by Sjögren et al was rounded to the next integer for this analysis. When rounding up to the next higher integer, the results were similar (pooled incidence $0.5 \%, 95 \% \mathrm{Cl} 0.1-1.9 \%$ ) $+\dagger$ for these analyses, we included only studies that reported outcomes separately for the specific subgroup of interest 


\section{Supplemental Material}

Periprocedural Bridging in Patients with Venous Thromboembolism: A Systematic Review

Supplemental Methods 1. Data Sources and Search Strategy

Supplemental Table 1. Characteristics of Included Studies, by Individual Study

Supplemental Table 2. Periprocedural Anticoagulation Management, by Individual Study

Supplemental Table 3. Quality of Individual Studies

Supplemental Table 4. Quality of Evidence: Periprocedural Bridging in Patients with Previous VTE 


\section{Supplemental Methods 1. Data Sources and Search Strategy}

The PubMed and Embase databases were searched from inception to December 7, 2017, for published articles in any language on the association between periprocedural anticoagulation management (bridging with short acting anticoagulants vs. no bridging) in adults on chronic anticoagulation treatment with vitamin $\mathrm{K}$ antagonists (VKA) for secondary prevention of venous thromboembolism who required interruption of VKA for an invasive elective procedure. Following search strategy was implemented in PubMed:

(()(()(()(()(temporary[tw] OR temporarily[tw]) AND (discontinue[tw] OR discontinuous[tw] OR discontinuation[tw])) OR management[tw] OR ((anticoagulation[tw] OR anticoagulant[tw] OR anticoagulants[tw] OR anticoagulate[tw] OR anti-coagulation[tw] OR anti-coagulant[tw] OR anticoagulants[tw] OR anti-coagulate[tw]) AND (interrupt[tw] OR interrupted[tw] OR interruption[tw] OR bridge[tw] OR bridging[tw] OR wean[tw] OR weaned[tw] OR weaning[tw] OR taper[tw] OR tapers[tw] OR tapered[tw] OR tapering[tw] OR suspend[tw] OR suspended[tw] OR suspending[tw] OR suspension[tw] OR cease[tw] OR ceased[tw] OR ceasing[tw] OR cessation[tw] OR cessations[tw] OR ceasing[tw] OR stop[tw] OR stopping[tw] OR stops[tw] OR stopped[tw]) AND (operative OR operation OR operate OR operatively OR surgery[tw] OR surgeries[tw] OR surgical[tw] OR surgically[tw] OR procedure[tw] OR procedures[tw] OR procedural[tw] OR preoperative[tw] OR preoperative[tw] OR perioperative[tw] OR peri-operative[tw])) OR Bridging[tw]))))))))

AND

((("Surgical Procedures, Operative"[Mesh] OR "Operative Surgical Procedure" OR "Operative Surgical Procedures" OR "Operative Procedures" OR "Operative Procedure" OR invasiv* OR procedur* OR "Post-operative Procedure" OR "Postoperative Procedure" OR "Post-operative Procedures" OR "Postoperative Procedures" OR "Pre-operative Procedure" OR "Preoperative Procedure" OR "Preoperative Procedures" OR "Preoperative Procedures" OR peri-procedural OR periprocedural OR periprocedure OR periprocedure OR "Preoperative Care"[Mesh] OR "Preoperative Care" OR "Pre- 
operative Care" OR "Intraoperative Care"[Mesh] OR "Intra-operative Care" OR "Intraoperative Care" OR "Postoperative Care"[Mesh] OR "Post-operative Care" OR "Postoperative Care" OR "Perioperative Care"[Mesh] OR "Peri-operative Care" OR "Perioperative Care" OR "Peroperative Care" OR "Per-operative Care" OR "perioperative period"[Mesh] OR peri-operative OR perioperative OR pre-operative OR preoperative OR post-operative OR postoperative)))))

AND

((("Venous Thrombosis"[Mesh] OR DVT OR VTE OR "venous thrombosis" OR "venous thromboses" OR "deep vein thrombosis" OR "deep vein thromboses" OR "pulmonary embolus" OR "pulmonary emboli" OR "pulmonary embolism" OR "thromboembolism" OR "thromboembolic")))

AND

((("Anticoagulants/administration and dosage"[Mesh] OR "Anticoagulants/adverse effects"[Mesh] OR "Anticoagulants/therapeutic use"[Mesh] OR "Vitamin K/administration and dosage"[Mesh] OR "Vitamin K/adverse effects"[Mesh] OR "Vitamin K/agonists"[Mesh] OR "Vitamin K/antagonists and inhibitors"[Mesh] OR "Vitamin K/therapeutic use"[Mesh] OR "Vitamin K/therapy"[Mesh] OR "Warfarin/administration and dosage"[Mesh] OR "Warfarin/adverse effects"[Mesh] OR "Warfarin/therapeutic use"[Mesh] OR "Coumarins/administration and dosage"[Mesh] OR "Coumarins/adverse effects"[Mesh] OR "Coumarins/therapeutic use"[Mesh] OR "Factor Xa Inhibitors"[Mesh] OR "Heparin/administration and dosage"[Mesh] OR "Heparin/adverse effects"[Mesh] OR "Heparin/analogs and derivatives"[Mesh] OR "Heparin/therapeutic use"[Mesh] OR "Factor Xa Inhibitors"[Pharmacological Action] OR warfarin OR acenocoumarol OR phenprocoumon OR coumadin OR dicumarol OR phenindione OR "vitamin K antagonist" OR VKA OR dabigatran OR edoxaban OR rivaroxaban OR apixaban OR Heparin OR "Low-Molecular-Weight Heparin" OR "LMW heparin" OR UFH OR "unfractionated heparin" OR Dalteparin OR Enoxaparin OR Nadroparin OR Tinzaparin)))This search strategy was adapted for searching the Embase database. 
We also searched for unpublished articles by reviewing guidelines ${ }^{1}$ and previous systematic reviews on periprocedural anticoagulation, ${ }^{2,3}$ screening of bibliographies of retrieved articles, and searching in the ClinicalTrials.gov and the International Clinical Trials Registry Platforms (ICTRP) databases. 
Supplemental Table 1. Characteristics of Included Studies, by Individual Study

\begin{tabular}{|c|c|c|c|c|c|c|c|c|}
\hline Study & Study Design & Setting & $\begin{array}{l}\text { Study Population and VTE } \\
\text { risk; \% Previous VTE in } \\
\text { Overall Study Population }\end{array}$ & $\begin{array}{l}\text { Indication for } \\
\text { Bridging }\end{array}$ & $\begin{array}{l}\text { Planned Invasive } \\
\text { Procedure }\end{array}$ & $\begin{array}{l}\text { Intervention / } \\
\text { Control }\end{array}$ & $\begin{array}{l}\text { Proce- } \\
\text { dures, } n\end{array}$ & $\begin{array}{l}\text { Study } \\
\text { Sponsor }\end{array}$ \\
\hline Ahmed, 2010 & $\begin{array}{l}\text { Cohort, } \\
\text { retrospective }\end{array}$ & $\begin{array}{l}1 \text { teaching hospital, } \\
\text { Minnesota, USA }\end{array}$ & VTE risk NR; $8 \%$ & $\begin{array}{l}\text { At the discretion of } \\
\text { the provider }\end{array}$ & $\begin{array}{l}\text { Anti-arrhythmic } \\
\text { device surgery }\end{array}$ & $\begin{array}{l}\text { I: LMWH, UFH } \\
\text { C: no bridging }\end{array}$ & $\begin{array}{l}\text { I: } 12 \\
\text { C: } 5\end{array}$ & $\begin{array}{l}\text { Non- } \\
\text { profit }\end{array}$ \\
\hline Baijkin, 2009 & $\begin{array}{l}\text { Cohort, } \\
\text { prospective* }\end{array}$ & $\begin{array}{l}1 \text { oral surgery } \\
\text { clinic, Serbia }\end{array}$ & VTE risk NR; $16 \%$ & $\begin{array}{l}\text { Random } \\
\text { assignment }\end{array}$ & $\begin{array}{l}\text { Simple extraction of } \\
\geq 1 \text { tooth }\end{array}$ & $\begin{array}{l}\text { I: LMWH } \\
\text { C: continued VKA }\end{array}$ & $\begin{array}{l}\text { I: } 19 \\
\text { C: } 15^{+}\end{array}$ & NR \\
\hline Birnie, 2013 & $\begin{array}{l}\text { Cohort, } \\
\text { prospective* }\end{array}$ & $\begin{array}{l}17 \text { centers in } \\
\text { Canada, } 1 \text { in Brazil }\end{array}$ & $\begin{array}{l}\text { moderate to high VTE risk; } \\
5 \%\end{array}$ & $\begin{array}{l}\text { Random } \\
\text { assignment }\end{array}$ & $\begin{array}{l}\text { Antiarrhythmic } \\
\text { device surgery }\end{array}$ & $\begin{array}{l}\text { I: LMWH, UFH } \\
\text { C: continued VKA† }\end{array}$ & $\begin{array}{l}\text { I: } 16 \\
\text { C: } 21+\end{array}$ & $\begin{array}{l}\text { Non- } \\
\text { profit }\end{array}$ \\
\hline Breen, 2013 & $\begin{array}{l}\text { Cohort, } \\
\text { retrospective }\end{array}$ & $\begin{array}{l}1 \text { tertiary care } \\
\text { hospital, Australia }\end{array}$ & $\begin{array}{l}\text { Patients who received } \\
\text { LMWH bridging, any VTE risk; } \\
27 \%\end{array}$ & $\begin{array}{l}\text { At the discretion of } \\
\text { the provider }\end{array}$ & $\begin{array}{l}\text { Various major and } \\
\text { minor procedures }\end{array}$ & $\begin{array}{l}\text { I: LMWH } \\
\text { C: - }\end{array}$ & $\begin{array}{l}\text { I: } 29 \\
\text { C: }-\end{array}$ & $\mathrm{NR}$ \\
\hline Burbury, 2011 & $\begin{array}{l}\text { Cohort, } \\
\text { prospective }\end{array}$ & $\begin{array}{l}1 \text { hospital, } \\
\text { Australia }\end{array}$ & $\begin{array}{l}\text { on warfarin }>6 \text { weeks, any } \\
\text { VTE risk; } 22 \%\end{array}$ & $\begin{array}{l}\text { At the discretion of } \\
\text { the provider, based } \\
\text { on VTE risk }\end{array}$ & $\begin{array}{l}\text { Various major and } \\
\text { minor procedures }\end{array}$ & $\begin{array}{l}\text { I: LMWH } \\
\text { C: no bridging }\end{array}$ & $\begin{array}{l}\text { I: } 0 \\
\text { C: } 39\end{array}$ & NR \\
\hline Clark, 2015 & $\begin{array}{l}\text { Cohort, } \\
\text { retrospective }\end{array}$ & $\begin{array}{l}\text { Integrated health } \\
\text { care system, } \\
\text { Colorado, USA }\end{array}$ & any VTE risk; $100 \%$ & $\begin{array}{l}\text { At the discretion of } \\
\text { the provider, based } \\
\text { on therapy plans }\end{array}$ & $\begin{array}{l}\text { Various major and } \\
\text { minor procedures }\end{array}$ & $\begin{array}{l}\text { I: short-acting } \\
\text { anticoagulant } \\
\text { C: no bridging }\end{array}$ & $\begin{array}{l}\text { I: } 555 \\
\text { C: } 1257\end{array}$ & $\begin{array}{l}\text { Non- } \\
\text { profit }\end{array}$ \\
\hline $\begin{array}{l}\text { Constans, } \\
2007\end{array}$ & $\begin{array}{l}\text { Cohort, } \\
\text { prospective }\end{array}$ & $\begin{array}{l}1 \text { tertiary care } \\
\text { hospital, Spain }\end{array}$ & $\begin{array}{l}\text { Adults requiring bridging due } \\
\text { to endoscopy, any VTE risk; } \\
10 \%\end{array}$ & $\begin{array}{l}\text { All study patients; } \\
\text { probably all with } \\
\text { VKA interruption }\end{array}$ & $\begin{array}{l}\text { Gastroscopy or } \\
\text { colonoscopy }\end{array}$ & $\begin{array}{l}\text { I: LMWH } \\
\text { C: - }\end{array}$ & $\begin{array}{l}\text { I: } 10 \\
\text { C: }-\end{array}$ & NR \\
\hline Douketis, 2005 & $\begin{array}{l}\text { Cohort, } \\
\text { prospective }\end{array}$ & 1 hospital, Canada & $\begin{array}{l}\text { Patients requiring bridging } \\
\text { due to procedure, any VTE } \\
\text { risk; } 29 \%\end{array}$ & $\begin{array}{l}\text { All study patients; } \\
\text { reason for bridging } \\
\text { decision unclear }\end{array}$ & $\begin{array}{l}\text { Various major and } \\
\text { minor procedures }\end{array}$ & $\begin{array}{l}\text { I: LMWH } \\
\text { C: - }\end{array}$ & $\begin{array}{l}\text { I: } 21 \\
\text { C: }-\end{array}$ & NR \\
\hline Dunn, 2007 & $\begin{array}{l}\text { Cohort, } \\
\text { prospective }\end{array}$ & $\begin{array}{l}24 \text { sites in North } \\
\text { America }\end{array}$ & $\begin{array}{l}\text { Outpatients for whom } \\
\text { bridging was planned, VTE } \\
\text { risk NR; } 37 \%\end{array}$ & $\begin{array}{l}\text { At the discretion of } \\
\text { the physician }\end{array}$ & $\begin{array}{l}\text { Various major and } \\
\text { minor procedures }\end{array}$ & $\begin{array}{l}\text { I: LMWH } \\
\text { C: - }\end{array}$ & $\begin{array}{l}\text { I: } 96 \\
\text { C: - }\end{array}$ & Industry \\
\hline Eisele, 2012 & $\begin{array}{l}\text { Cohort, } \\
\text { retrospective }\end{array}$ & $\begin{array}{l}\text { Multiple hospitals } \\
\text { and physician } \\
\text { offices, Germany }\end{array}$ & $\begin{array}{l}\text { Patients who received } \\
\text { cetroparin bridging, VTE risk } \\
\text { NR; } 29 \%\end{array}$ & $\begin{array}{l}\text { At the discretion of } \\
\text { the physician }\end{array}$ & $\begin{array}{l}\text { Surgeries, } \\
\text { endoscopy, } \\
\text { angiography }\end{array}$ & $\begin{array}{l}\text { I: LMWH } \\
\text { C: - }\end{array}$ & $\begin{array}{l}\text { I: } 69 \\
\text { C: - }\end{array}$ & Industry \\
\hline $\begin{array}{l}\text { Fernandez, } \\
2009\end{array}$ & $\begin{array}{l}\text { Cohort, } \\
\text { prospective }\end{array}$ & NR & Any VTE risk; $44 \%$ & $\begin{array}{l}\text { VTE }<3 \text { months ago } \\
\text { and non-high } \\
\text { bleeding risk } \\
\text { procedure }\end{array}$ & $\begin{array}{l}\text { High and low } \\
\text { bleeding risk } \\
\text { procedures }\end{array}$ & $\begin{array}{l}\text { I: LMWH } \\
\text { C: no bridging }\end{array}$ & $\begin{array}{l}\text { I: } 24 \\
\text { C: } 14\end{array}$ & NR \\
\hline Garcia, 2008 & & 101 physician & Outpatients, any VTE risk; & At the discretion of & Outpatient & I: LMWH & I: 15 & Industry \\
\hline
\end{tabular}




\begin{tabular}{|c|c|c|c|c|c|c|c|c|}
\hline & prospective & practices, USA & $14 \%$ & the physician & procedures & C: no bridging & C: 179 & \\
\hline $\begin{array}{l}\text { Hammerstingl, } \\
2009\end{array}$ & $\begin{array}{l}\text { Cohort, } \\
\text { prospective }\end{array}$ & $\begin{array}{l}\text { Unclear, probably } \\
1 \text { hospital, } \\
\text { Germany }\end{array}$ & $\begin{array}{l}\text { Patients receiving bridging } \\
\text { with therapeutic enoxaparin, } \\
\text { VTE risk NR; } 14 \%\end{array}$ & Not clear & $\begin{array}{l}\text { Minor surgery and } \\
\text { invasive procedures }\end{array}$ & $\begin{array}{l}\text { I: LMWH } \\
\text { C: - }\end{array}$ & $\begin{array}{l}\text { I: } 10 \\
\text { C: }-\end{array}$ & NR \\
\hline Hwang, 2017 & $\begin{array}{l}\text { Cohort, } \\
\text { retrospective }\end{array}$ & $\begin{array}{l}1 \text { tertiary care } \\
\text { center, South } \\
\text { Korea }\end{array}$ & $\begin{array}{l}\text { Referred to clinic for } \\
\text { bridging, VTE risk NR; 70\% }\end{array}$ & $\begin{array}{l}\text { At the discretion of } \\
\text { the provider }\end{array}$ & $\begin{array}{l}\text { Various major and } \\
\text { minor procedures }\end{array}$ & $\begin{array}{l}\text { I: LMWH } \\
\text { C: - }\end{array}$ & $\begin{array}{l}\text { I: } 34 \\
\text { C: }-\end{array}$ & $\begin{array}{l}\text { Non- } \\
\text { profit }\end{array}$ \\
\hline Jaffer, 2005 & $\begin{array}{l}\text { Cohort, } \\
\text { retrospective }\end{array}$ & $\begin{array}{l}1 \text { anticoagulation } \\
\text { clinic, Ohio, USA }\end{array}$ & $\begin{array}{l}\text { High enough VTE risk to } \\
\text { justify bridging; } 26 \%\end{array}$ & $\begin{array}{l}\text { Sufficiently high } \\
\text { VTE risk }\end{array}$ & $\begin{array}{l}\text { Various major and } \\
\text { minor procedures }\end{array}$ & $\begin{array}{l}\text { I: LMWH } \\
\text { C: - }\end{array}$ & $\begin{array}{l}\text { I: } 18 \\
\text { C: }-\end{array}$ & NR \\
\hline $\begin{array}{l}\text { Klamroth, } \\
2010\end{array}$ & $\begin{array}{l}\text { Cohort, } \\
\text { prospective }\end{array}$ & $\begin{array}{l}\text { Unclear, probably } \\
1 \text { hospital, } \\
\text { Germany }\end{array}$ & Any VTE risk; $32 \%$ & $\begin{array}{l}\text { All patients without } \\
\text { contraindication to } \\
\text { LMWH }\end{array}$ & $\begin{array}{l}\text { Major }(75 \%) \text { and } \\
\text { minor surgeries }\end{array}$ & $\begin{array}{l}\text { I: LMWH } \\
\text { C: - }\end{array}$ & $\begin{array}{l}\text { I: } 63 \\
\text { C: }-\end{array}$ & NR \\
\hline $\begin{array}{l}\text { Majluf-Cruz, } \\
2011\end{array}$ & $\begin{array}{l}\text { Cohort, } \\
\text { prospective }\end{array}$ & NR & $\begin{array}{l}\text { Patients with recurrent VTE, } \\
\text { high VTE risk, } 100 \%\end{array}$ & $\begin{array}{l}\text { All study patients } \\
\text { (recurrent VTE) }\end{array}$ & $\begin{array}{l}\text { Various major and } \\
\text { minor procedures }\end{array}$ & $\begin{array}{l}\text { I: LMWH } \\
\text { C: rivaroxaban }+\end{array}$ & $\begin{array}{l}\text { I: } 152 \\
\text { C: } 158+\end{array}$ & NR \\
\hline Malato, 2010 & $\begin{array}{l}\text { Cohort, } \\
\text { prospective }\end{array}$ & $\begin{array}{l}1 \text { tertiary care } \\
\text { center, Italy }\end{array}$ & $\begin{array}{l}\text { Outpatients, any VTE risk; } \\
14 \%\end{array}$ & $\begin{array}{l}\text { All patients without } \\
\text { contraindication to } \\
\text { LMWH }\end{array}$ & $\begin{array}{l}\text { Various major and } \\
\text { minor procedures }\end{array}$ & $\begin{array}{l}\text { I: LMWH } \\
\text { C: - }\end{array}$ & $\begin{array}{l}\text { I: } 45 \\
\text { C: }-\end{array}$ & NR \\
\hline McBane, 2010 & $\begin{array}{l}\text { Cohort, } \\
\text { prospective }\end{array}$ & $\begin{array}{l}1 \text { tertiary care } \\
\text { clinic, USA }\end{array}$ & $\begin{array}{l}\text { Referred for VKA } \\
\text { management, any VTE risk; } \\
100 \%\end{array}$ & $\begin{array}{l}\text { Moderate to high } \\
\text { VTE risk patients }\end{array}$ & $\begin{array}{l}\text { Various major and } \\
\text { minor procedures }\end{array}$ & $\begin{array}{l}\text { I: LMWH } \\
\text { C: no bridging }\end{array}$ & $\begin{array}{l}\mathrm{I}: 342 \ddagger \\
\mathrm{C}: 152 \ddagger\end{array}$ & $\begin{array}{l}\text { Non- } \\
\text { profit }\end{array}$ \\
\hline Pengo, 2009 & $\begin{array}{l}\text { Cohort, } \\
\text { prospective }\end{array}$ & $\begin{array}{l}22 \text { anticoagulation } \\
\text { centers, Italy }\end{array}$ & Any VTE risk; $17 \%$ & $\begin{array}{l}\text { All requiring } \\
\text { periprocedural VKA } \\
\text { interruption }\end{array}$ & $\begin{array}{l}\text { Various high and low } \\
\text { bleeding risk } \\
\text { procedures }\end{array}$ & $\begin{array}{l}\text { I: LMWH } \\
\text { C: - }\end{array}$ & $\begin{array}{l}\text { I: } 210 \\
\text { C: - }\end{array}$ & $\begin{array}{l}\text { Non- } \\
\text { profit }\end{array}$ \\
\hline Sacullo, 2012 & $\begin{array}{l}\text { Cohort, } \\
\text { prospective }\end{array}$ & $\begin{array}{l}1 \text { tertiary care } \\
\text { center, Italy }\end{array}$ & $\begin{array}{l}\text { Cancer patients on long-term } \\
\text { VKA for whom bridging was } \\
\text { planned, any VTE risk; } 33 \%\end{array}$ & Indication unclear & $\begin{array}{l}\text { Major and minor } \\
\text { surgery, chemo- } \\
\text { therapy induced } \\
\text { thrombocytopenia }\end{array}$ & $\begin{array}{l}\text { I: LMWH } \\
\text { C: - }\end{array}$ & $\begin{array}{l}\text { I: } 52 \\
\text { C: }-\end{array}$ & NR \\
\hline $\begin{array}{l}\text { Santamaria, } \\
2013\end{array}$ & $\begin{array}{l}\text { Cohort, } \\
\text { prospective* }\end{array}$ & 10 hospitals, Spain & Qutpatients, any VTE risk; $6 \%$ & $\begin{array}{l}\text { All patients } \\
\text { requiring VKA } \\
\text { interruption for } \\
\text { outpatient surgery }\end{array}$ & $\begin{array}{l}\text { Outpatient surgical } \\
\text { or invasive } \\
\text { procedures }\end{array}$ & $\begin{array}{l}\text { I: LMWH or UFH } \\
\text { C: - }\end{array}$ & $\begin{array}{l}\text { I: } 10 \\
\text { C: - }\end{array}$ & Industry \\
\hline Sjögren, 2017 & $\begin{array}{l}\text { Cohort, } \\
\text { retrospective }\end{array}$ & $\begin{array}{l}\text { Multiple health } \\
\text { care centers, } \\
\text { Sweden }\end{array}$ & VTE risk NR; $41 \%$ & $\begin{array}{l}\text { At the discretion of } \\
\text { the provider }\end{array}$ & $\begin{array}{l}\text { Indication for VKA } \\
\text { interruption unclear }\end{array}$ & $\begin{array}{l}\text { I: LMWH } \\
\text { C: no bridging }\end{array}$ & $\begin{array}{l}\text { I: } 1331 \\
\text { C: } 1331 \S\end{array}$ & $\begin{array}{l}\text { Non- } \\
\text { profit }\end{array}$ \\
\hline Skeith, 2012 & $\begin{array}{l}\text { Cohort, } \\
\text { retrospective }\end{array}$ & $\begin{array}{l}1 \text { medical center, } \\
\text { Canada }\end{array}$ & $\begin{array}{l}\text { Patients with VTE events }>3 \\
\text { months ago; } 100 \%\end{array}$ & $\begin{array}{l}\text { Patients requiring } \\
\text { postinterventional } \\
\text { inpatient } \\
\text { treatment }\end{array}$ & $\begin{array}{l}\text { Various major and } \\
\text { minor procedures }\end{array}$ & $\begin{array}{l}\text { I: LMWH } \\
\text { C: no bridging }\end{array}$ & $\begin{array}{l}\text { I: } 152 \\
\text { C: } 482\end{array}$ & NR \\
\hline
\end{tabular}




\begin{tabular}{|c|c|c|c|c|c|c|c|c|}
\hline $\begin{array}{l}\text { Spyropoulos, } \\
2004\end{array}$ & $\begin{array}{l}\text { Cohort, } \\
\text { retrospective }\end{array}$ & $\begin{array}{l}\text { Integrated health } \\
\text { care system, USA }\end{array}$ & $\begin{array}{l}\text { Patients receiving bridging, } \\
\text { any VTE risk; } 36 \%\end{array}$ & $\begin{array}{l}\text { At the discretion of } \\
\text { the provider }\end{array}$ & $\begin{array}{l}\text { Various major and } \\
\text { minor procedures }\end{array}$ & $\begin{array}{l}\text { I: LMWH } \\
\text { C: - }\end{array}$ & $\begin{array}{l}\text { I: } 45 \\
\text { C: }-\end{array}$ & NR \\
\hline $\begin{array}{l}\text { Spyropoulos, } \\
2006\end{array}$ & $\begin{array}{l}\text { Cohort, } \\
\text { prospective }\end{array}$ & $\begin{array}{l}14 \text { centers, USA } \\
\text { and Canada }\end{array}$ & $\begin{array}{l}\text { On VKA for } \geq 3 \text { months, on } \\
\text { perioperative heparin for } \geq 2 \\
d \text {, any VTE risk; } 12 \%\end{array}$ & $\begin{array}{l}\text { At the discretion of } \\
\text { the provider }\end{array}$ & $\begin{array}{l}\text { Various major and } \\
\text { minor procedures }\end{array}$ & $\begin{array}{l}\text { I: LMWH or UFH } \\
\text { C: - }\end{array}$ & $\begin{array}{l}\text { I: } 22|| \\
\text { C: - }\end{array}$ & Industry \\
\hline Wilson, 2001 & $\begin{array}{l}\text { Cohort, } \\
\text { prospective }\end{array}$ & $\begin{array}{l}1 \text { anticoagulation } \\
\text { clinic, Canada }\end{array}$ & $\begin{array}{l}\text { Referred to clinic, high VTE } \\
\text { risk; } 55 \%\end{array}$ & High VTE risk & $\begin{array}{l}\text { Various major and } \\
\text { minor procedures }\end{array}$ & $\begin{array}{l}\text { I: LMWH } \\
\text { C: - }\end{array}$ & $\begin{array}{l}\text { I: } 26 \\
\text { C: }-\end{array}$ & NR \\
\hline $\begin{array}{l}\text { Wiszniewsky, } \\
2011\end{array}$ & $\begin{array}{l}\text { Cohort, } \\
\text { prospective }\end{array}$ & 1 clinic, Poland & $\begin{array}{l}\text { Thrombophilia or APS, high } \\
\text { to very high VTE risk; } 100 \%\end{array}$ & $\begin{array}{l}\text { High and very high } \\
\text { VTE risk }\end{array}$ & $\begin{array}{l}\text { Various major and } \\
\text { minor procedures }\end{array}$ & $\begin{array}{l}\text { I: LMWH } \\
\text { C: - }\end{array}$ & $\begin{array}{l}\text { I: } 63 \\
\text { C: }-\end{array}$ & NR \\
\hline
\end{tabular}

Abbreviations: APS, antiphospholipid antibody syndrome; LMWH, low molecular weight heparin; UFH, unfractionated heparin; VKA, vitamin K

antagonist; VTE, venous thromboembolism.

*these studies were designed as randomized controlled trials comparing bridging to continued VKA or comparing two different bridging

strategies. We considered these studies to be prospective cohorts for our systematic review, because none of these trials compared bridging and

VKA interruption without bridging.

† patients with continued anticoagulation during surgery or received periprocedural bridging with direct oral anticoagulants did not meet the inclusion criteria for our systematic review and were therefore not further considered for our analyses

¥ personal communication by the investigator

$\S$ comparison group was propensity score matched and weighted; actual overall number of patients with previous VTE was 2670 in the bridging and non-bridging group combined.

II Outcomes for patients with previous VTE were only available for patients in the group of patients who received UFH (rather than LMWH)

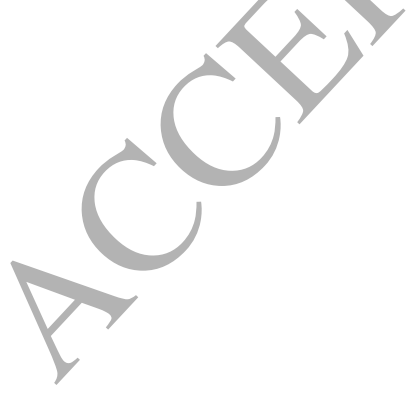


Supplemental Table 2. Periprocedural Anticoagulation Management, by Individual Study

\begin{tabular}{|c|c|c|c|c|c|c|c|c|c|}
\hline \multirow[b]{2}{*}{ Study } & \multirow[b]{2}{*}{$\begin{array}{l}\text { Peri- } \\
\text { procedural } \\
\text { Bridging }\end{array}$} & \multirow[b]{2}{*}{$\begin{array}{l}\text { Type of } \\
\text { Bridging } \\
\text { Anticoagulant }\end{array}$} & \multicolumn{3}{|c|}{ Preoperative Management } & \multirow[b]{2}{*}{$\begin{array}{l}\text { Restart of } \\
\text { LMWH, h }\end{array}$} & \multicolumn{2}{|c|}{ Postoperative Management } & \multirow[b]{2}{*}{ Stop of Bridging } \\
\hline & & & $\begin{array}{l}\text { VKA } \\
\text { Interruption, } \\
\text { d }\end{array}$ & $\begin{array}{l}\text { Dosing of Bridging } \\
\text { Anticoagulant }\end{array}$ & $\begin{array}{l}\text { Last Dose of } \\
\text { LMWH, } h\end{array}$ & & Restart of VKA & $\begin{array}{l}\text { Initial Dosing } \\
\text { of VKA }\end{array}$ & \\
\hline Ahmed, 2010 & Pre/post & LMWH, UFH & $3-5$ & therapeutic & $12-18$ & 24 & $\begin{array}{l}\text { Evening of } \\
\text { procedure }\end{array}$ & NR & $\begin{array}{l}\text { When INR } \\
\text { therapeutic }\end{array}$ \\
\hline Baijkin, 2009 & Pre/post & LMWH & $3-4$ & $\begin{array}{l}\text { Prophylactic or } \\
\text { subtherapeutic }\end{array}$ & $\geq 12$ & $\begin{array}{l}\text { Evening of } \\
\text { procedure }\end{array}$ & $\begin{array}{l}\text { Evening of } \\
\text { procedure }\end{array}$ & NR & $\begin{array}{l}\text { When INR } \\
\text { therapeutic }\end{array}$ \\
\hline Birnie, 2013 & Pre/post & LMWH, UFH & 5 & therapeutic & $>24$ & 24 & $\begin{array}{l}\text { Evening or morning } \\
\text { after procedure }\end{array}$ & $\begin{array}{l}\text { At } \\
\text { investigator's } \\
\text { discretion }\end{array}$ & $\begin{array}{l}\text { When INR } \\
\text { therapeutic }\end{array}$ \\
\hline Breen, 2013 & Pre/post & LMWH & 5 & $\begin{array}{l}\text { Low or } \\
\text { therapeutic }\end{array}$ & Day prior & $\begin{array}{l}\text { At provider's } \\
\text { discretion }\end{array}$ & $\begin{array}{l}\text { At provider's } \\
\text { discretion }\end{array}$ & NR & NR \\
\hline Burbury, 2011 & Post only & LMWH & $1 *$ & $\begin{array}{l}\text { Prophylactic or } \\
\text { therapeutic }\end{array}$ & NA & $12-24$ & $12-24 \mathrm{~h}$ & maintenance & $\begin{array}{l}\text { When INR } \\
\text { therapeutic }\end{array}$ \\
\hline Clark, 2015 & $\begin{array}{l}\text { Not } \\
\text { specified }\end{array}$ & LMWH, UFH & NR & $\begin{array}{l}\text { Prophylactic or } \\
\text { therapeutic }\end{array}$ & $\mathrm{NR}$ & NR & NR & NR & NR \\
\hline Constans, 2007 & Pre/post & LMWH & $\begin{array}{l}\text { Aceno- } \\
\text { coumarol: } 3 \\
\text { Warfarin: } 5\end{array}$ & prophylactic & $\geq 12$ & $<24$ & $\begin{array}{l}1 \text { day after } \\
\text { procedure }\end{array}$ & maintenance & $\begin{array}{l}\text { On day } 3-4 \\
\text { postoperatively }\end{array}$ \\
\hline Douketis, 2005 & Pre/post & LMWH & $5-6$ & $\begin{array}{l}\text { Prophylactic or } \\
\text { therapeutic }\end{array}$ & $\geq 12$ & 24 & $\begin{array}{l}\text { Evening or day } \\
\text { after procedure }\end{array}$ & NR & NR \\
\hline Dunn, 2007 & Pre/post & LMWH & 5 & therapeutic & Morning prior & $12-24$ & $\begin{array}{l}\text { Evening of } \\
\text { procedure or day } \\
\text { after }\end{array}$ & maintenance & $\begin{array}{l}\text { When INR } \\
\text { therapeutic }\end{array}$ \\
\hline Eisele, 2012 & Pre/post & LMWH & Mean 6.4 & $\begin{array}{l}\text { Prophylactic, sub- } \\
\text { or therapeutic }\end{array}$ & Mean 16.2 & Mean 12.2 & Mean 3.6d & NR & $\begin{array}{l}\text { Overall duration } \\
\text { mean } 7 \mathrm{~d}\end{array}$ \\
\hline $\begin{array}{l}\text { Fernandez, } \\
2009\end{array}$ & $\begin{array}{l}\text { Pre/post, } \\
\text { post only }\end{array}$ & LMWH & $4-5$ & Therapeutic & 24 & $12-48$ & $\begin{array}{l}\text { Evening of } \\
\text { procedure or day } \\
\text { after }\end{array}$ & NR & NR \\
\hline Garcia, 2008 & $\begin{array}{l}\text { Not } \\
\text { specified }\end{array}$ & $\begin{array}{l}\text { Almost } \\
\text { exclusively } \\
\text { LMWH }\end{array}$ & $\begin{array}{l}>7(6.3 \%) \\
\leq 5(87.4 \%)\end{array}$ & NR & NR & NR & $\mathrm{NR}$ & NR & NR \\
\hline $\begin{array}{l}\text { Hammerstingl, } \\
2009\end{array}$ & Pre/post & LMWH & $5-6$ & therapeutic & Evening prior & NR & NR & NR & $\begin{array}{l}\text { When INR } \\
\text { therapeutic }\end{array}$ \\
\hline
\end{tabular}




\begin{tabular}{|c|c|c|c|c|c|c|c|c|c|}
\hline \multirow[b]{2}{*}{ Study } & \multirow[b]{2}{*}{$\begin{array}{l}\text { Peri- } \\
\text { procedural } \\
\text { Bridging }\end{array}$} & \multirow[b]{2}{*}{$\begin{array}{l}\text { Type of } \\
\text { Bridging } \\
\text { Anticoagulant }\end{array}$} & \multicolumn{3}{|c|}{ Preoperative Management } & \multicolumn{4}{|c|}{ Postoperative Management } \\
\hline & & & $\begin{array}{l}\text { VKA } \\
\text { Interruption, } \\
\text { d }\end{array}$ & $\begin{array}{l}\text { Dosing of Bridging } \\
\text { Anticoagulant }\end{array}$ & $\begin{array}{l}\text { Last Dose of } \\
\text { LMWH, h }\end{array}$ & $\begin{array}{l}\text { Restart of } \\
\text { LMWH, h }\end{array}$ & Restart of VKA & $\begin{array}{l}\text { Initial Dosing } \\
\text { of VKA }\end{array}$ & Stop of Bridging \\
\hline Hwang, 2017 & Pre/post & LMWH & 5 & therapeutic & Morning prior & $\begin{array}{l}48-72 \text { after } \\
\text { major, } 12-24 \\
\text { after minor } \\
\text { surgery }\end{array}$ & $\begin{array}{l}\text { With LMWH or day } \\
\text { after }\end{array}$ & loading & $\begin{array}{l}\text { When INR } \\
\text { therapeutic on } \\
2 d\end{array}$ \\
\hline Jaffer, 2005 & Pre/post & LMWH & $\begin{array}{l}5-6 \\
\text { depending } \\
\text { on INR }\end{array}$ & therapeutic & 24 & 24 & $\begin{array}{l}\text { Day of procedure } \\
\text { or day after }\end{array}$ & maintenance & $\begin{array}{l}\text { When INR } \\
\text { therapeutic on } \\
2 d\end{array}$ \\
\hline Klamroth, 2010 & Pre/post & LMWH & 7 & Half-therapeutic & $\geq 12$ & $8-12$ & $\begin{array}{l}\text { At provider's } \\
\text { discretion (mean } \\
5 d \text { ) }\end{array}$ & NR & $\begin{array}{l}\text { When INR } \\
\text { therapeutic }\end{array}$ \\
\hline $\begin{array}{l}\text { Majluf-Cruz, } \\
2011\end{array}$ & $\begin{array}{l}\text { Not } \\
\text { specified }\end{array}$ & $\begin{array}{l}\text { LMWH, } \\
\text { rivaroxabant }\end{array}$ & 10 & prophylactic & NR & NR & NR & NR & NR \\
\hline Malato, 2010 & Pre/post & LMWH & 5 & $\begin{array}{l}\text { Subtherapeutic or } \\
\text { prophylactic }\end{array}$ & Evening priór & 12 & $\begin{array}{l}\text { Day after } \\
\text { procedure }\end{array}$ & maintenance & $\begin{array}{l}\text { When INR } \\
\text { therapeutic }\end{array}$ \\
\hline McBane, 2010 & $\begin{array}{l}\text { Pre/post, } \\
\text { pre only, } \\
\text { post only }\end{array}$ & LMWH & 5 & therapeutic & $\begin{array}{l}24 \text { (only } 1 / 2 \\
\text { dose) }\end{array}$ & $24-48$ & Mean 3.9d & maintenance & $\begin{array}{l}\text { When INR } \\
\text { therapeutic on } \\
2 d\end{array}$ \\
\hline Pengo, 2009 & Pre/post & LMWH & 5 & $\begin{array}{l}\text { Subtherapeutic or } \\
\text { prophylactic }\end{array}$ & $\geq 12$ & $\geq 12$ & $\begin{array}{l}\text { Day after } \\
\text { procedure }\end{array}$ & loading & $\begin{array}{l}\text { When INR } \\
\text { therapeutic, } \geq 6 \mathrm{~d}\end{array}$ \\
\hline Sacullo, 2012 & Pre/post & LMWH & 5 & $\begin{array}{l}\text { Prophylactic or } \\
\text { subtherapeutic }\end{array}$ & Evening prior & 12 & $\begin{array}{l}\text { Day after } \\
\text { procedure }\end{array}$ & maintenance & $\begin{array}{l}\text { When INR } \\
\text { therapeutic }\end{array}$ \\
\hline $\begin{array}{l}\text { Santamaria, } \\
2013\end{array}$ & Pre/post & LMWH, UFH & $\begin{array}{l}\text { Aceno- } \\
\text { coumarol: } 3 \\
\text { Warfarin: } 5\end{array}$ & prophylactic & $\geq 12$ & $\begin{array}{l}\text { Evening of } \\
\text { procedure }\end{array}$ & $\begin{array}{l}\text { Day after } \\
\text { procedure }\end{array}$ & NR & $\begin{array}{l}5-6 d \text { after } \\
\text { procedure }\end{array}$ \\
\hline Sjögren, 2017 & $\begin{array}{l}\text { Not } \\
\text { specified }\end{array}$ & LMWH & NR & $\begin{array}{l}\text { Prophylactic, sub- } \\
\text { or therapeutic }\end{array}$ & NR & NR & NR & NR & NR \\
\hline Skeith, 2012 & Post only & LMWH & 5 & $\begin{array}{l}\text { Prophylactic or } \\
\text { therapeutic }\end{array}$ & NA & $\begin{array}{l}\text { Morning after } \\
\text { procedure }\end{array}$ & Day of surgery & NR & $\begin{array}{l}\text { At discharge or } \\
\text { when INR >1.9 }\end{array}$ \\
\hline $\begin{array}{l}\text { Spyropoulos, } \\
2004\end{array}$ & Pre/post & LMWH, UFH & $\geq 4$ & $\begin{array}{l}\text { Prophylactic or } \\
\text { therapeutic }\end{array}$ & $\begin{array}{l}\text { Morning prior, } \\
\text { or evening } \\
\text { prior at } 1 / 2 \text { dose } \\
\text { if procedure } \\
\text { after 10am }\end{array}$ & $\begin{array}{l}\text { Evening of } \\
\text { procedure }\end{array}$ & $\begin{array}{l}\text { Evening of } \\
\text { procedure }\end{array}$ & maintenance & $\begin{array}{l}\text { When INR } \\
\text { therapeutic on } \\
2 d\end{array}$ \\
\hline
\end{tabular}




\begin{tabular}{|c|c|c|c|c|c|c|c|c|c|}
\hline \multirow[b]{2}{*}{ Study } & \multirow[b]{2}{*}{$\begin{array}{l}\text { Peri- } \\
\text { procedural } \\
\text { Bridging }\end{array}$} & \multirow[b]{2}{*}{$\begin{array}{l}\text { Type of } \\
\text { Bridging } \\
\text { Anticoagulant }\end{array}$} & \multicolumn{3}{|c|}{ Preoperative Management } & \multicolumn{4}{|c|}{ Postoperative Management } \\
\hline & & & $\begin{array}{l}\text { VKA } \\
\text { Interruption, } \\
\text { d }\end{array}$ & $\begin{array}{l}\text { Dosing of Bridging } \\
\text { Anticoagulant }\end{array}$ & $\begin{array}{l}\text { Last Dose of } \\
\text { LMWH, h }\end{array}$ & $\begin{array}{l}\text { Restart of } \\
\text { LMWH, h }\end{array}$ & ) $>$ & $\begin{array}{l}\text { Initial Dosing } \\
\text { of VKA }\end{array}$ & Stop of Bridging \\
\hline $\begin{array}{l}\text { Spyropoulos, } \\
2006\end{array}$ & $\begin{array}{l}\text { Pre/post, } \\
\text { pre only, } \\
\text { post only }\end{array}$ & LMWH & $\mathrm{NR}$ & $\begin{array}{l}\text { Therapeutic and } \\
\text { non-therapeutic }\end{array}$ & NR & NR & $\begin{array}{l}<24 \mathrm{~h} \text { after } \\
\text { procedure in } 38.3 \%\end{array}$ & NR & $\begin{array}{l}\text { Overall duration } \\
\text { mean } 6.8 \mathrm{~d}\end{array}$ \\
\hline Wilson, 2001 & Pre/post & LMWH & 5 & $\begin{array}{l}\text { Prophylactic or } \\
\text { therapeutic }\end{array}$ & NR & 12 & $\begin{array}{l}\text { Evening of } \\
\text { procedure }\end{array}$ & maintenance & $\begin{array}{l}\text { When INR } \\
\text { therapeutic }\end{array}$ \\
\hline $\begin{array}{l}\text { Wiszniewsky, } \\
2011\end{array}$ & Pre/post & LMWH & 2 & Half-therapeutic & $\begin{array}{l}2-12 \mathrm{~h} \text { at } 1 / 4 \\
\text { therapeutic } \\
\text { dose }\end{array}$ & & d 4 after surgery & loading & $\begin{array}{l}\text { When INR } \\
\text { therapeutic on } \\
2 d\end{array}$ \\
\hline
\end{tabular}

Abbreviations: $d$, day; h, hours; INR, international normalized ratio; LMWH, low molecular weight heparin; NA, not applicable; NR, not reported;

UFH, unfractionated heparin; VKA, vitamin K antagonist.

*and administration of 3mg intravenous Vitamin $\mathrm{K}$

† this treatment arm was not included in our study, as it did not meet the inclusion criteria

$\ddagger$ this treatment arm was not included in our analysis, because outcomes were not specifically reported for patients with prior venous thromboembolism 
Supplemental Table 3. Quality of Individual Studies

\begin{tabular}{|c|c|c|c|c|c|c|c|}
\hline \multirow[t]{2}{*}{ Cohort Studies } & \multirow{2}{*}{$\begin{array}{l}\text { Consecutive } \\
\text { Enrollment }\end{array}$} & \multirow{2}{*}{$\begin{array}{l}\text { Existence of } \\
\text { Protocol before } \\
\text { Enrollment }\end{array}$} & \multicolumn{2}{|c|}{ Intervention / Control } & \multirow{2}{*}{$\begin{array}{l}\text { Blinded } \\
\text { Outcome } \\
\text { Assessment }\end{array}$} & \multirow{2}{*}{$\begin{array}{l}\text { Loss to Follow-up } \\
<5 \%\end{array}$} & \multirow[t]{2}{*}{ Risk of Bias } \\
\hline & & & $\begin{array}{l}\text { Setting } \\
\text { Similar }\end{array}$ & $\begin{array}{l}\text { Time Frame } \\
\text { Similar }\end{array}$ & & & \\
\hline Ahmed, 2010 & yes & no & yes & yes & no & NR & high \\
\hline Baijkin, 2009* & NA* & yes & NA & NA & no & NR & very high* \\
\hline Birnie, 2013* & $N A^{*}$ & yes & NA & NA & yes & yes & very high* \\
\hline Breen, 2013 & PY & no & NA & NA & no & NR & very high \\
\hline Burbury, 2011 & PN & yes & NA & NA & no & yes & very high \\
\hline Clark, 2015 & yes & no & yes & yes & no & NR & high \\
\hline Constans, 2007 & yes & yes & NA & NA & no & NR & very high \\
\hline Douketis, 2005 & yes & no & NA & NA & no & NR & very high \\
\hline Dunn, 2007 & no & yes & NA & NA & no & NR & very high \\
\hline Eisele, 2012 & no & no & NA & NA & no & no & very high \\
\hline Fernandez, $2009+$ & PN & PN & PY & yes & PN & NR & very high \\
\hline Garcia, 2008 & no & yes & yes & yes & no & yes & high \\
\hline Hammerstingl, 2009 & yes & yes & NA & NA & no & NR & very high \\
\hline Hwang, 2017 & no & no & NA & NA & no & NR & very high \\
\hline Jaffer, 2005 & yes & PN & NA & NA & no & NR & very high \\
\hline Klamroth, 2010 & yes & PY & NA & NA & no & NR & very high \\
\hline Majluf-Cruz, $2011+$ & PN & PY & NA & NA & no & NR & very high \\
\hline Malato, 2010 & yes & yes & NA & NA & no & yes & very high \\
\hline McBane, 2010 & yes & yes & yes & yes & PY & yes & moderate \\
\hline Pengo, 2009 & yes & yes & NA & NA & no & NR & very high \\
\hline Sacullo, 2012 & yes & yes & NA & NA & no & yes & very high \\
\hline Santamaria, 2013* & NA* & yes & NA & NA & no & no & very high* \\
\hline Sjögren, 2017 & no & no & NR & NR & no & NR & very high \\
\hline Skeith, 2012 & no & $\mathrm{PN}$ & yes & yes & no & yes & high \\
\hline Spyropoulos, 2004 & no & PN & NA & NA & no & NR & very high \\
\hline Spyropoulos, 2006 & yes & PN & NA & NA & yes & NR & very high \\
\hline Wilson, 2001 & yes & yes & NA & NA & no & NR & very high \\
\hline Wiszniewsky, 2011 & no & yes & NA & NA & no & NR & very high \\
\hline
\end{tabular}

Abbreviations: NA, not applicable; NR, not reported; PN, probably no; PY, probably yes. Quality of observational studies was assessed using

criteria adapted from the American College of Chest Physicians working group for the $9^{\text {th }}$ guidelines on antithrombotic therapy and prevention of 
thrombosis, which included guidance to for quality assessment of cohort studies without internal controls. ${ }^{4}$ Observational or nonrandomized interventional studies were considered to be at high risk of bias and were downgraded to moderate risk if the study accounted for and reported all of the reported quality elements. On the other hand, they were upgraded to very high risk if they used a single-arm cohort design without an internal comparison group, or there are severe or multiple problems with these elements. ${ }^{5}$

*these studies were designed as randomized controlled trials comparing bridging to continued VKA or comparing two different bridging strategies. We considered these studies to be prospective cohorts for our systematicreview, because none of these trials compared bridging and VKA interruption without bridging.

† conference abstract, no corresponding full text published 
Supplemental Table 4. Quality of Evidence: Periprocedural Bridging in Patients with Previous VTE

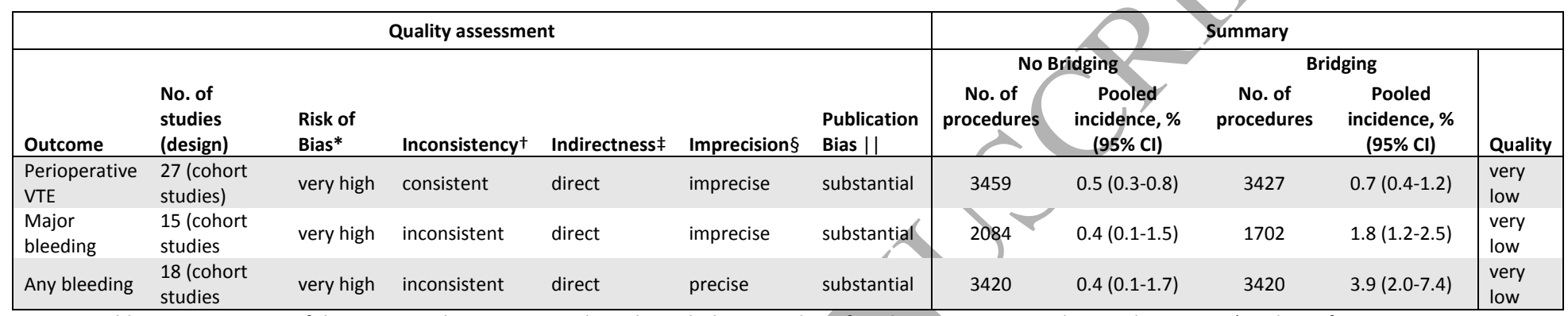

Abbreviations: $\mathrm{Cl}$, confidence interval; VTE, venous thromboembolism. Quality of evidence was assessed using the GRADE (grading of

recommendations assessment, development, and evaluation) framework. ${ }^{6}$ Observational studies were considered low quality of evidence, and were downgraded to very low quality depending on risk of bias, inconsistency, indirectness, imprecision, and publication bias. One of four possible scores (high, moderate, low, or very low) for the quality of the overall body of evidence was assigned for each outcome.

*based on following criteria: failure to develop appropriate eligibility criteria, lack of internal control group (single-arm cohorts), flawed measurement of exposure and/or outcome, inadequacy of control for confounding, incomplete follow-up.

† based on differences in effect sizes of studies comparing outcomes in both exposure groups, their overlap in $95 \%$ confidence intervals, and statistical heterogeneity

$\ddagger$ evidence was considered indirect if the population, the intervention, or the outcomes that were measured in the included studies differed from those of interest in our systematic review, or if there were no head-to-head comparisons available $\S$ based on optimal information size criterion and 95\% confidence interval

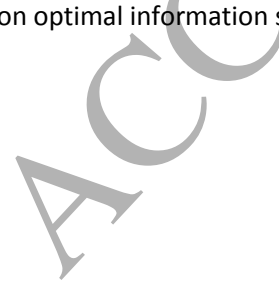


II The potential for publication bias was determined by searching for unpublished literature and conducting a sensitivity analysis excluding conference abstracts. A quantitative assessment of publication bias was not supported by the data (mostly single-arm studies).

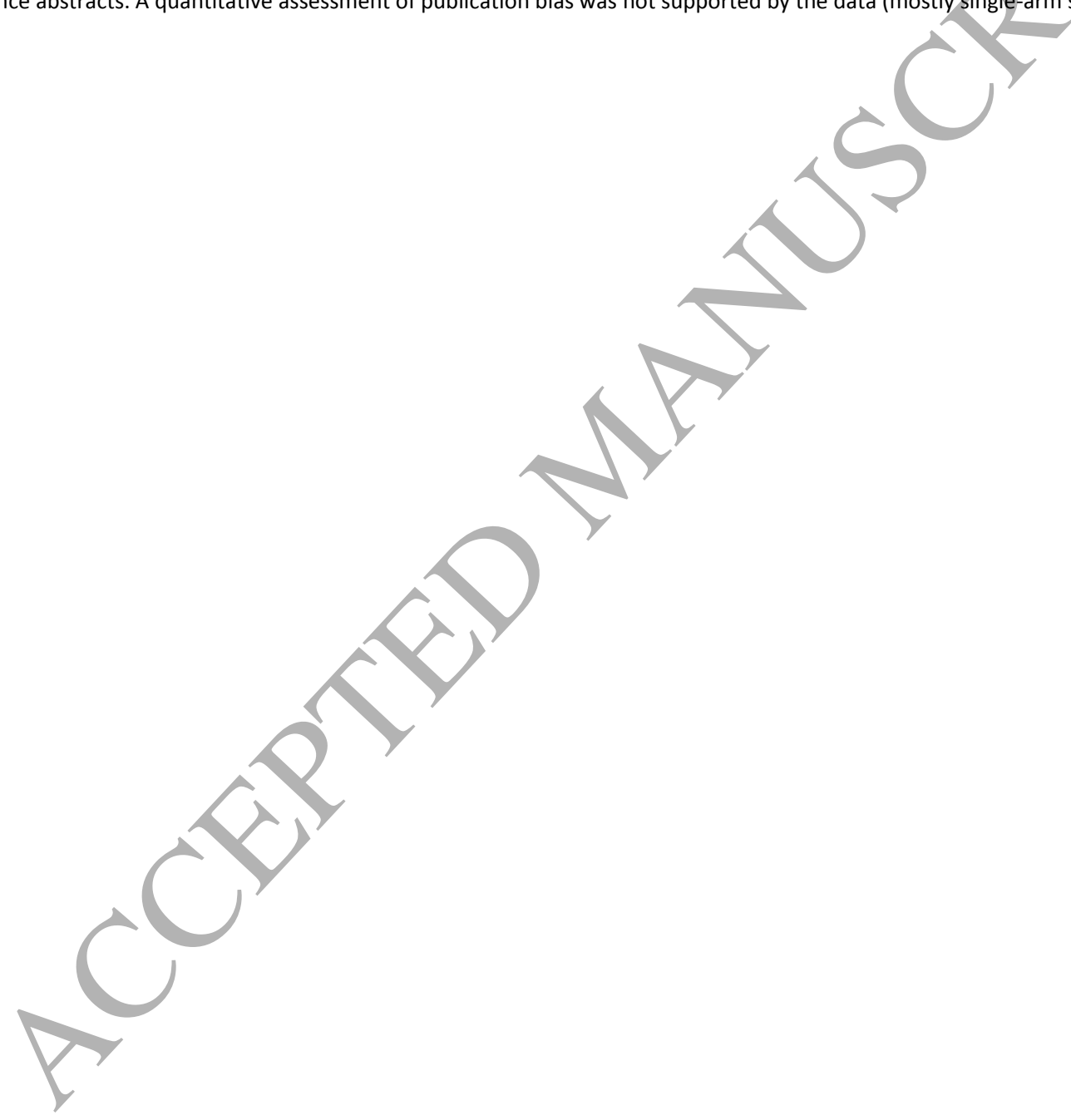




\section{References}

1. Douketis JD, Spyropoulos AC, Spencer FA, Mayr M, Jaffer AK, Eckman MH, Dunn AS, Kunz R and American College of Chest P. Perioperative management of antithrombotic therapy:

Antithrombotic Therapy and Prevention of Thrombosis, 9th ed: American College of Chest Physicians Evidence-Based Clinical Practice Guidelines. Chest. 2012;141:e326S-350S.

2. Siegal D, Yudin J, Kaatz S, Douketis JD, Lim W and Spyropoulos AC. Periprocedural heparin bridging in patients receiving vitamin $\mathrm{K}$ antagonists: systematic review and meta-analysis of bleeding and thromboembolic rates. Circulation. 2012;126:1630-1639.

3. Dunn AS and Turpie AG. Perioperative management of patients receiving oral anticoagulants: a systematic review. Arch Intern Med. 2003;163:901-908.

4. Guyatt GH, Norris SL, Schulman S, Hirsh J, Eckman MH, AkI EA, Crowther M, Vandvik PO, Eikelboom JW, McDonagh MS, Lewis SZ, Gutterman DD, Cook DJ and Schunemann HJ. Methodology for the development of antithrombotic therapy and prevention of thrombosis guidelines:

Antithrombotic Therapy and Prevention of Thrombosis, 9th ed: American College of Chest Physicians Evidence-Based Clinical Practice Guidelines. Chest. 2012;141:53S-70S.

5. Guyatt GH, Oxman AD, Vist G, Kunz R, Brozek J, Alonso-Coello P, Montori V, AkI EA, Djulbegovic B, Falck-YtterY, Norris SL, Williams JW, Jr., Atkins D, Meerpohl J and Schunemann HJ. GRADE guidelines: 4. Rating the quality of evidence--study limitations (risk of bias). J Clin Epidemiol. 2011;64:407-415.

6. Guyatt G, Oxman AD, Akl EA, Kunz R, Vist G, Brozek J, Norris S, Falck-Ytter Y, Glasziou P, DeBeer H, Jaeschke R, Rind D, Meerpohl J, Dahm P and Schunemann HJ. GRADE guidelines: 1. Introduction-GRADE evidence profiles and summary of findings tables. J Clin Epidemiol. 2011;64:383394. 